\title{
Stakeholders' Engagement on Nature-Based Solutions: A Systematic Literature Review
}

\author{
Vera Ferreira ${ }^{1, * \mathbb{D}}$, Ana Paula Barreira ${ }^{2}$, Luís Loures ${ }^{3}\left[\mathbb{C}^{\circ}\right.$, Dulce Antunes ${ }^{4} \mathbb{(}$ and \\ Thomas Panagopoulos $1, *($ (D)
}

1 Research Center for Tourism, Sustainability and Well-being, University of Algarve, Campus de Gambelas, 8000 Faro, Portugal

2 Center for Advanced Studies in Management and Economics, Faculty of Economics, University of Algarve, Campus de Gambelas, 8000 Faro, Portugal; aprodrig@ualg.pt

3 Research Center for Endogenous Resource Valorization, Polytechnic Institute of Portalegre (IPP), 7300-110 Portalegre, Portugal; lcloures@ipportalegre.pt

4 Mediterranean Institute for Agriculture, Environment and Development, FCT, University of Algarve, Campus of Gambelas, 8000 Faro, Portugal; mantunes@ualg.pt

* Correspondence: vlferreira@ualg.pt (V.F.); tpanago@ualg.pt (T.P.); Tel.: +00351-289800900 (T.P.); Fax: +00351-289818419 (T.P.)

Received: 30 November 2019; Accepted: 9 January 2020; Published: 15 January 2020 updates

\begin{abstract}
Cities are facing a broad range of social and environmental challenges due to the current pressure of global urbanization. Nature-based solutions aim to utilize green infrastructure to improve people's health and wellbeing. The design of urban environments must embrace the individual ideals of citizens and stakeholders which can only be achieved if effective methods of communication, involvement, and feedback are ensured. Such a procedure creates trust during its implementation, helping to take ownership and stewardship of processes and sites. This systematic literature review explores the current state of the art regarding citizen and stakeholder participation in nature-based solutions (NBS). The search on the SCOPUS database identified 142 papers in total that met the inclusion criteria. The participation analysis was separated in two areas: (a) analysis of perceptions, preferences, and perspectives of citizens and stakeholders, and (b) analysis of the participation process, including challenges and opportunities, motivations, methods and frameworks, and collaborative governance. The results revealed that stakeholder and citizen participation or collaboration in nature-based solutions is increasingly recognized as promising; however, research in several related domains is still lacking.
\end{abstract}

Keywords: nature-based solutions; green infrastructure; stakeholder participation; collaborative governance; urban sustainability; citizen perceptions

\section{Introduction}

Due to the current pressure of global urbanization, quality of life and sustainability of European cities have gained political impetus in the last decade. Cities are facing a broad range of challenges, such as climate change, human health issues, social inequity and poverty, degradation, loss of natural capital and the provision of ecosystem services, and an enhanced readiness to deal with disasters (e.g., floods) [1,2].

The concept of biophilia advanced the idea that contact with nature plays a fundamental role in human physical and mental wellbeing [3]. Additionally, there was an emerging need of using natural components and their multiple functions, to increase sustainable development into the cities, dealing with recognized issues. Key challenges for sustainable cities are to significantly increase their resources 
and efficiency in addressing issues relating to transportation, climate change, and water and air quality. Such actions should exert profound economic, social, and environmental impacts, resulting in a better quality of life (including health and social cohesion), jobs, and growth.

The importance of nature and its functions in cities have been studied for many years, using different metaphors, such as urban forests (UF), ecosystem services (ES), urban green spaces (UGS), biophilic urbanism (BU), green infrastructure (GI) and, more recently, nature-based solutions (NBS) [3-6]. While ES are often valued in terms of immediate benefits to human well-being and economy, and UF, UGS, BU, and GI focus on the provision of these ES through biodiversity protection, NBS simultaneously addresses diverse societal challenges in the long-term, allowing benefits to people and the environment itself [7]. Nature-based solutions have largely evolved from previous ecosystem-based concepts and/or principles (e.g., ecosystem services, green infrastructures, ecosystem-based management, and natural capital), but it also pays attention to the social and economic benefits of resource-efficient and universal solutions that combine technical, business, finance, governance, regulatory, and social innovation [8]. Parker and Baro [9] reviewed the literature dealing with GI and identified that the concept is diffuse and imprecise, with a focus on environmental, ecological, and social planning and policy, neglecting its economic, health, and wellbeing effects, as well as its performance. Given that NBS is broad in definition and scope, it can be considered as an umbrella for the previously- mentioned concepts [6]. Sarabi et al. [10] reviewed the literature incorporating the concept and concluded that it remains ambiguous and fragmented-perhaps due, in no small part, to the fact that articles addressing the concept only started appearing quite recently (the first references dating back only to 2015). Relying on Sarabi et al. [10], we feel the definition of NBS proposed by the EC [1] assumes an understanding of the concept similar to the approach followed in the current work: "actions inspired by, supported by or copied from nature and which aim to help societies address a variety of environmental, social and economic challenges in sustainable ways".

The stakeholder involvement in urban green infrastructure (GI), including urban forest (UF) or urban green space (UGS), is not new and has greatly advanced in recent decades [11-13]. However, looking at the more recent NBS concept the human context is critical and is gaining increasing attention from scientists and practitioners as potential solutions to enhance socio-ecological systems resilience. Recent work suggests more attention should be given to the incorporation of local and indigenous knowledge into formulating and applying solutions $[8,14]$. Though, the involvement of locals is still rarely adopted; mainly resulting from the general perception that multi-stakeholder initiatives slow down urban planning and policy development processes due to a lack of consensus and different sectoral interests [8].

\section{Theoretical Framework and Rationale for the Review}

Some authors have presented literature reviews on the topic of GI [9,15-17] or NBS [10]; however, those works deviated from the focus provided in the current review. Parker and Simpson [15] present a systematic quantitative review on how public green infrastructure contributes to city livability, informing urban planners, policymakers, and researchers about the psychological, physiological, general well-being, and wider societal benefits that humans receive as a result of experiencing GI. Parker and Boro [9] reviewed the publications dealing with GI but they also looked mainly at the benefits generated by GI. The work of Verkataramanan et al. [16] is centered on the role of GI for stormwater and flood management and its impacts on human health and social wellbeing. Zuniga-Teran and Gerlak [17] reviewed publications on urban green spaces to assess how those infrastructures promote social justice. Sarabi et al. [10] aimed to develop a conceptual theory for NBS based on the current state of the art; as such, their analysis excluded publications dealing with the technical and physical dimensions of NBS. All these previous works did not specifically examine the participation of citizens and stakeholders in the processes of NBS.

Figure 1 represents a conceptual understanding of NBS, their benefits, planning process, and implementation. The various links within and between ecological and social systems are accounted for 
in the process. We consider that NBS needs to be embedded in the existing policies, supported by urban planning and adopted in joint dialogues between policy, society, and science. Urban planning can contribute with relevant spatial information for decision support concerning the choice for the location of projects and how they relate with societal challenges, the identification of alternative solutions, and the measurement of their respective impacts [18]. Nature-based solutions can enhance natural capital and promote biodiversity while delivering other co-benefits [7]. NBS operationalizes the concept of ecosystem services that are the contributions (co-benefits) that ecosystems, in combination with other inputs, make to human well-being.

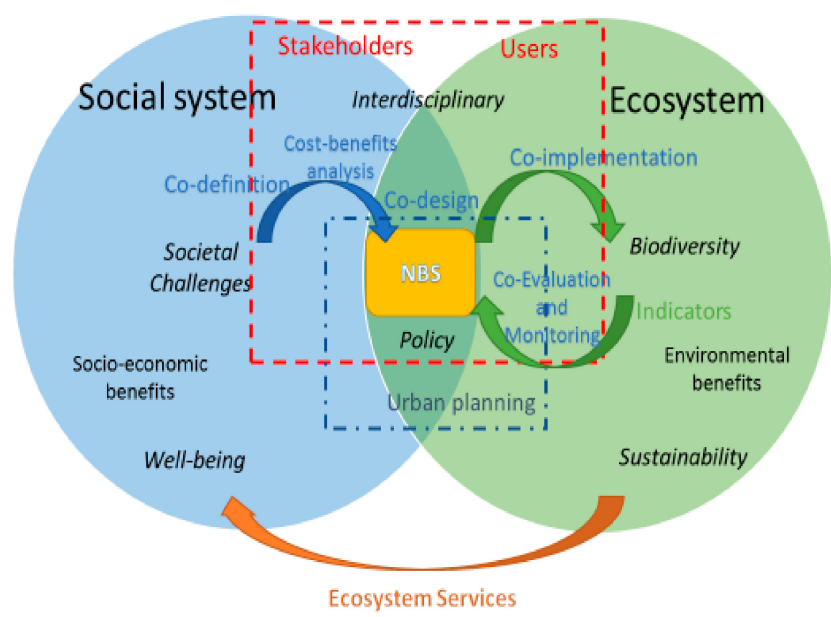

Figure 1. Conceptual understanding of nature-based solutions. Source: Own elaboration.

The focus of this systematic literature review is to bring up the role played by the participation of stakeholders and citizens on the identification of problems and solutions for urban green areas. Previous works have revised citizens' participation in the context of GI, e.g., [19,20]; but they have adopted parcel approaches by considering only either users or citizens actively involved in initiatives of GI.

The application of NBS serves as the primary focus of this literature review. However, as noted, it is a recent concept that, of necessity, includes the human component-indeed, stakeholder engagement is essential to the success of such initiatives. This literature review, therefore, includes the other concepts mentioned above, aiming thereby to provide a complete picture of public participation in NBS processes. The objective is to understand the progress of citizen participation and stakeholders over the years. We investigate the perceptions, preferences, and perspectives of different actors, the participation drivers and motivations, the participation methods and frameworks, the collaborative governance, and the participation challenges and opportunities. This analysis is performed aiming to answer the following research questions:

- (RQ1) How are the perceptions, preferences, and perspectives of the citizens and stakeholders taken into consideration in the literature addressing NBS?

- $\quad(\mathrm{RQ2})$ Which motivations trigger the citizens' and stakeholders' engagement?

- (RQ3) What are the main benefits and costs sought by citizens and stakeholders resulting from the participation processes of NBS?

- (RQ4) What are the major difficulties and opportunities raised by the engagement of citizens/stakeholders?

- (RQ5) Which approaches are predominant in collaborative governance to involve citizens and stakeholders in participatory processes of NBS? 


\section{Materials and Methods}

A systematic literature review was conducted to provide an overview of research to date related to the citizen and stakeholder participation and engagement on NBS. This systematic literature review is based on the Preferred Reporting Items for Systematic Reviews (PRISMA) guidelines (http://prisma-statement.org/).

\subsection{Identification}

A search for publications addressing NBS-related concepts, as well as stakeholder and citizen participation, was conducted in June of 2019 using the Scopus search engine. Scopus was selected due to its broader coverage compared to other academic search engines. The following combination of keywords was performed using Boolean operators:

TITLE-ABS-KEY ("nature-based solution" OR "green infrastructure" OR "biophilic infrastructure" OR "urban green space" OR "biophilic design" OR "urban forest" OR "urban biodiversity") AND TITLE-ABS-KEY ("stakeholder" OR "public" OR “citizen" OR "resident" OR "community" OR "expert") AND TITLE-ABS-KEY ("engagement" OR "participation" OR "perceptions" OR "perspectives" OR "involvement" OR "collaboration" OR "preferences") AND TITLE-ABS-KEY ("urban").

The initial search yielded a total of 814 records; however, 147 records were excluded by source and document type. We limited our research to publications on journals, excluding conference proceedings, book series, books, and trade publications. Only journal articles were included in the systematic literature review because we want to focus on high-quality empirical studies ensured by the peer-review process undertaken by academic journals. Literature review articles dealing with the topic of urban green solutions, but not addressing the issue of citizens' and stakeholders' participation, were not included in this systematic review; however, they were considered in the discussion to highlight the main contribution of the current work. Additionally, we only included articles written in the English language, thus excluding 30 records in various other languages. The excluded publications were organized by criterion of exclusion.

\subsection{Screening and Eligibility Criteria}

Explicit inclusion and exclusion criteria were defined prior to screening of abstracts and full texts; Figure 2 details the inclusion and exclusion process according to the PRISMA flow diagram. To be included, articles needed to indicate that the public or stakeholders were engaged in some stage of NBS process. First, we screened the abstracts; 287 records were excluded because they provided no evidence of such participation. Posteriorly, we attempt to access the full text of those articles and only 294 were available. After reading the full-text article, a total of 142 papers were included. The reasons for exclusion were:

- Conceptual articles without evidence of empirical work;

- Not relevant with respect to participatory processes (i.e., without analysis of opportunities and challenges, methods, approaches, motivations, perceptions, and preferences);

- Studies outside the urban context. 
PRISMA 2009 Flow Diagram
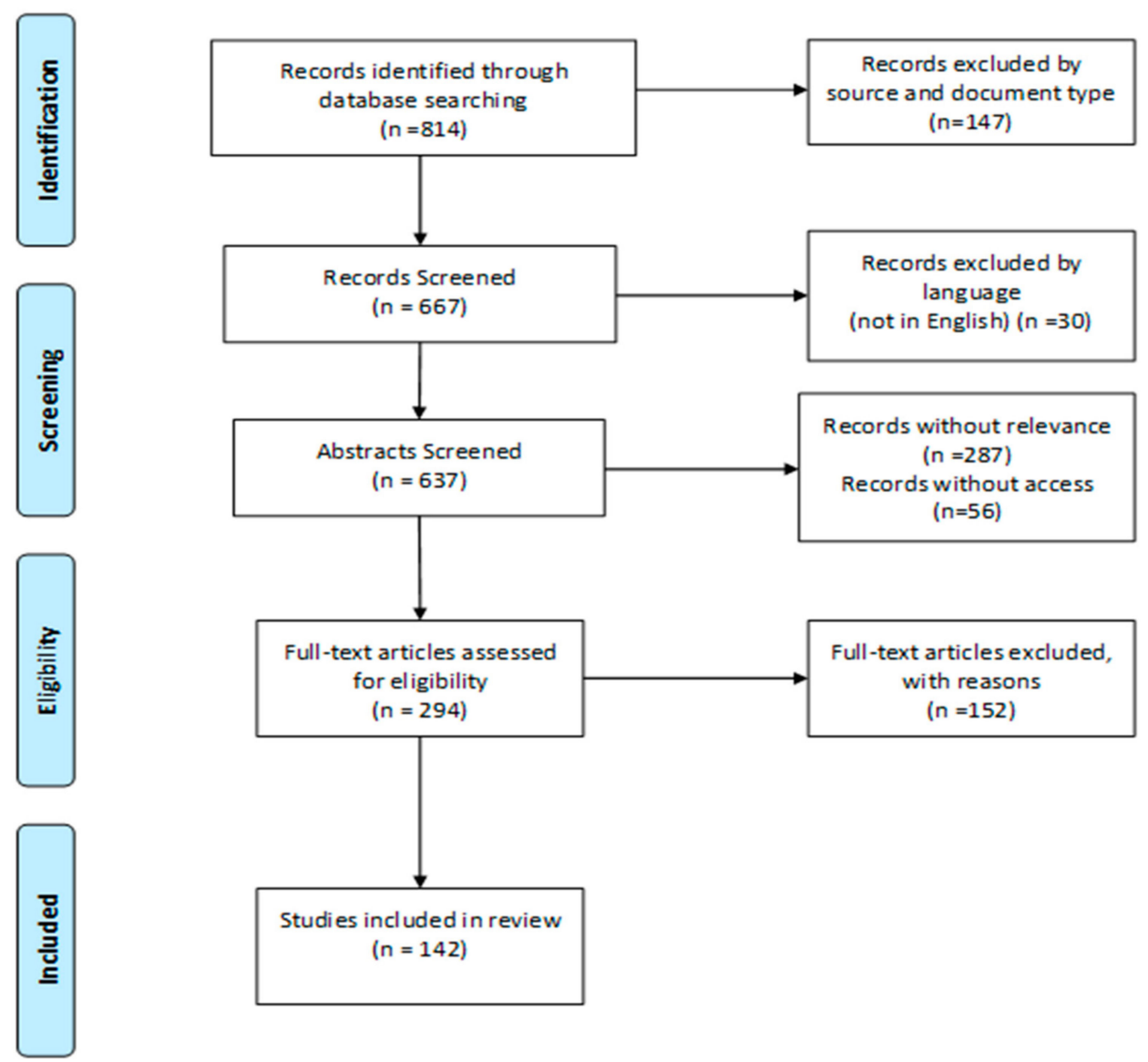

Figure 2. Preferred Reporting Items for Systematic Reviews (PRISMA) expression of the systematic literature review.

\section{Results}

\subsection{General Characteristics of the Body of Research}

\subsubsection{Temporal Progression of the Research on the Issue}

The research methodology did not impose a restriction publication year. However, before 2000 there are few papers, without online access, that mentioned public participation or perceptions on urban forests. Only in 2000 and 2001, as displayed in Figure 3, appeared the first papers (with online access) about the relevance of public perceptions and preferences on urban forest [11,21]. A paper published in 2005 relates a collaborative urban forest-planning initiative in Helsinki, Finland, that was begun in 1995 [12]. The term "urban green space" related to resident perceptions appeared in $2006[22,23]$. The concept of "green infrastructure" related to public participation in urban planning emerges in 2009 [13]. "Nature-based solution" appears for the first time in 2016 [14].

Figure 3 shows an exponential increase of publications in this field after 2015, with $78.2 \%$ of the articles being published after this year. This finding suggests that citizens and stakeholder participation in NBS constitutes a growing research area. 


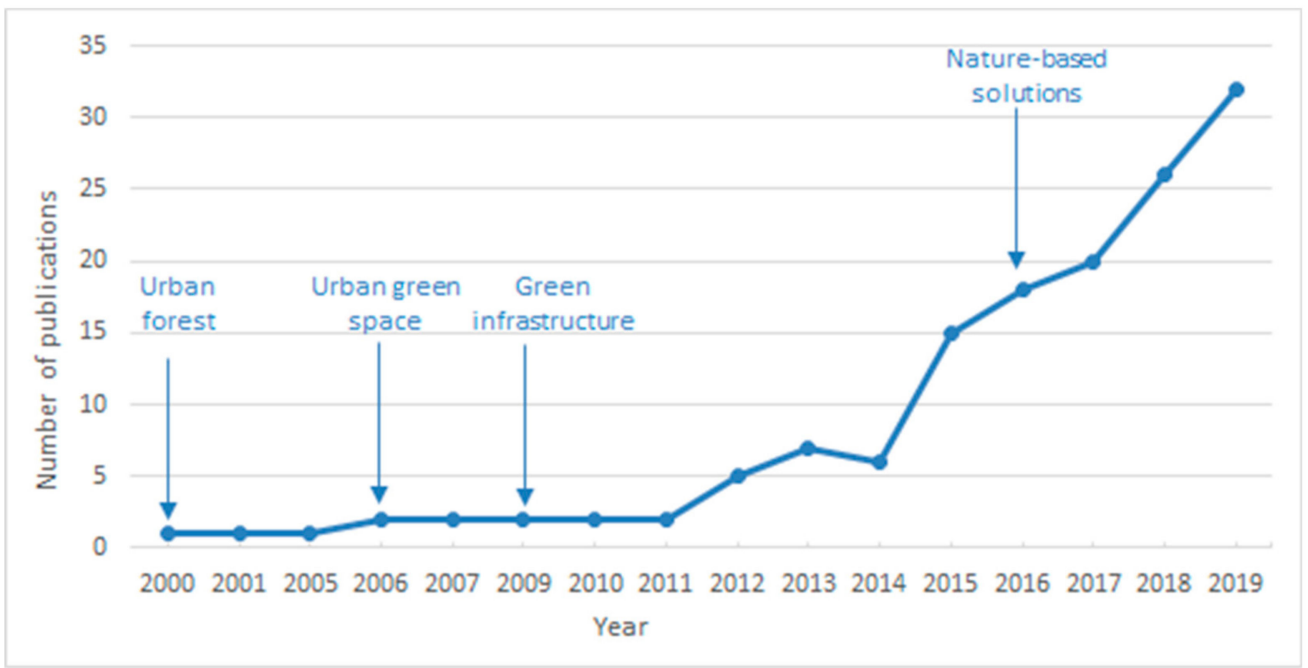

Figure 3. Number of selected published articles, per year, on citizen and stakeholder participation in NBS.

\subsubsection{Geographical Distribution of Research on the Issue}

The distribution of publications by country is presented in Figure 4 (for countries with more than two study cases).

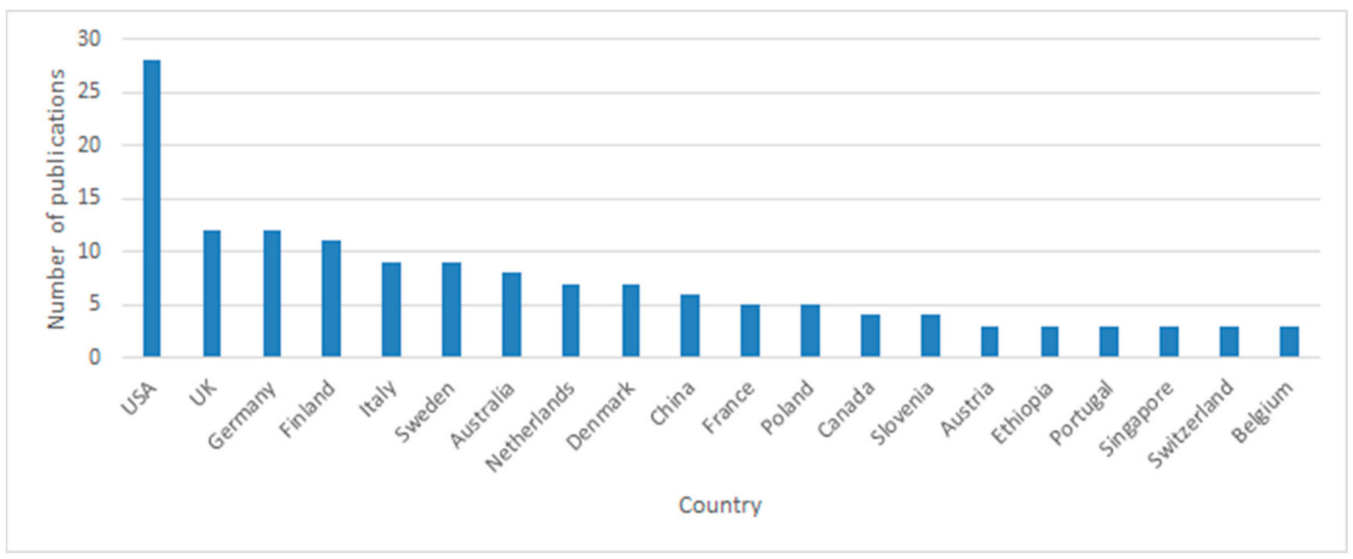

Figure 4. The distribution by country of the selected publications.

The United States plays a leading role in the research on citizen and stakeholder participation and engagement in NBS, with a total of $28(19.7 \%)$ publications, followed by the United Kingdom and Germany (both with 8.5\%). A total of 47 countries were accounted for in the selected articles, encompassing applications mainly in Europe (113 study cases corresponding to 76 publications and 28 countries) but also in North America (33 studies/publications and 3 countries) and Asia (22 studies corresponding to 21 publications and 10 countries). Of the 76 European publications, it is interesting to stress that only 12 have applications in southern countries (Portugal, Italy, and Greece) despite the fact that they face a higher risk in the near future of hazards relating to climate change [24]. Curiously, we find only one publication addressing this issue in the countries of South America [25].

The first published studies [11,21] were from the United Kingdom and Nigeria and, in 2019, there were 32 published papers, comprehending 24 countries and five continents.

\subsubsection{Coverage of the Issue by Journals}

Figure 5 shows the distribution of the selected research articles per journal. Regarding this distribution, Urban Forestry and Urban Greening is the leading source of published articles $(30.3 \%$ of 
publications), followed by Landscape and Urban Planning (12.0\% of publications) and Sustainability $(7.0 \%)$. A total of 45 different journals were identified.

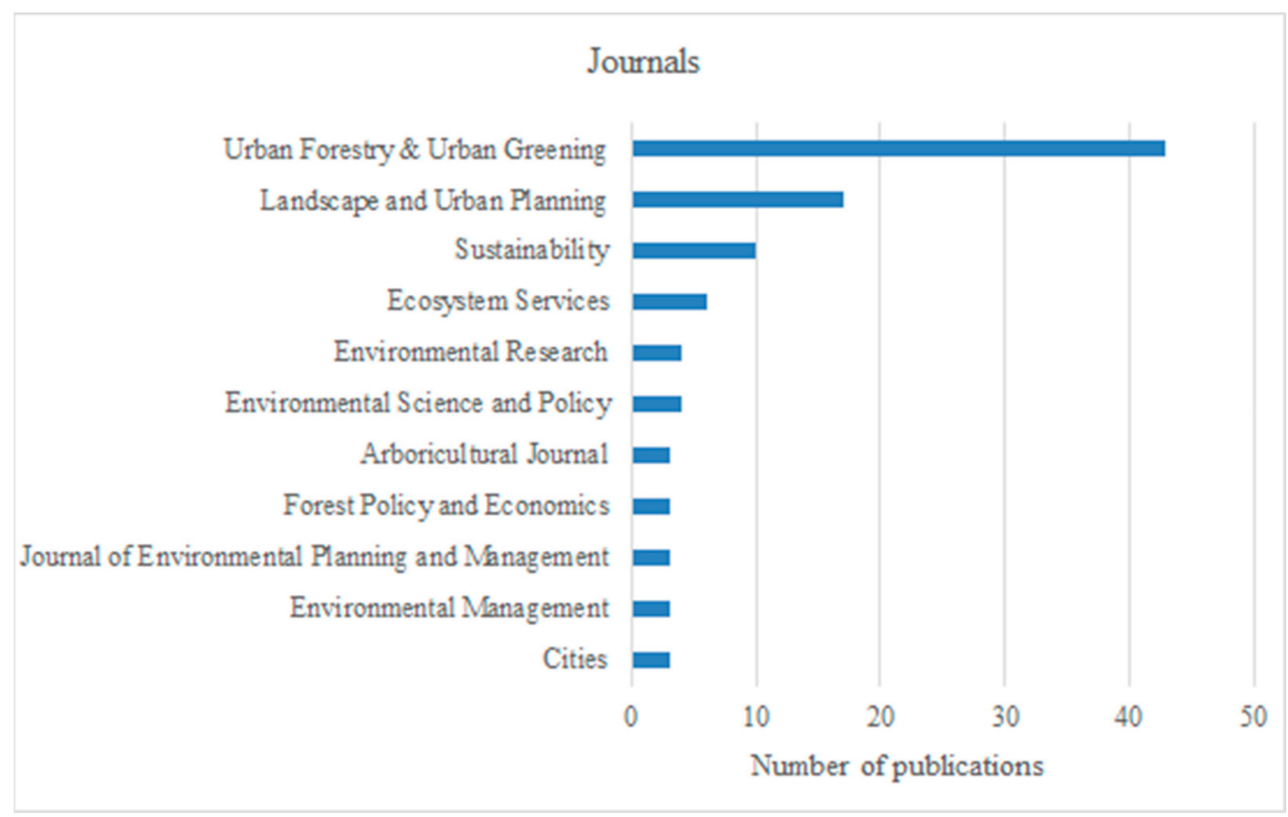

Figure 5. The main journals publishing on the issue of citizen and stakeholder participation on NBS.

\subsubsection{General Focus of the Articles}

The published articles were further explored to better address the research questions. They were separated into two general areas according to their main objective: (a) analysis of perceptions, preferences, and perspectives of the stakeholders, and (b) analysis of the participation process. While some articles paid attention to the perceptions, preferences, and perspectives of stakeholders as an important component of participation process, other studies focused on the analysis of elements of the participatory process. Within these two areas, articles can be grouped into sub-areas according to specific objectives, as shown in Table 1. This table also shows the total number of publications per area (n). Almost half the studies (45.8\%) reported stakeholders' and citizens' perceptions, preferences, and perspectives regarding NBS-in particular, the level of satisfaction (through the identification of benefits and costs) and the preferences (through the identification of preferred attributes). The remaining body of publications (54.2\%) analyzes the participatory process, with more studies on methods and frameworks and fewer on the main drivers and participant motivations.

In addition to the identification of focus areas, a data visualization technique known as "Word Cloud" was produced for each of the areas. The most common and obvious words in these two areas ("urban", "green", "management", "planning", and "environmental") were not included in this analysis to make clear the differences between them. The word clouds are presented in Figure 6. Looking at the publications that focus on the perceptions, preferences, and perspectives of the stakeholders, some of the most frequent words were "park," "trees," "landscape," "ecosystem" and "services". Words that emerged when examining the participatory processes were "social", "community", "participation", "governance", and "policy". These results highlight that the literature focused on the first area deals with the cognitive image of the ideal NBS developed by citizens and stakeholders, whereas the literature addressing the second area is more concerned with public participation in practice. 
Table 1. The areas and subareas of reviewed papers that were grouped according to the central aim of the study. The number of publications (n) is shown.

\begin{tabular}{ccc}
\hline Area & Sub-Area & Aim \\
\hline & $\begin{array}{c}\text { Benefits and costs } \\
(\mathrm{n}=35)\end{array}$ & $\begin{array}{c}\text { Focus on citizen and/or stakeholder } \\
\text { perceptions of benefits and costs of NBS }\end{array}$ \\
\cline { 2 - 3 } $\begin{array}{c}\text { Analysis of perceptions, preferences } \\
\text { and perspectives on NBS }(\mathrm{n}=\mathbf{6 5})\end{array}$ & $\begin{array}{c}\text { Attributes } \\
(\mathrm{n}=16)\end{array}$ & $\begin{array}{c}\text { Focus on citizen and/or stakeholder } \\
\text { preferences of specific attributes and design } \\
\text { of NBS }\end{array}$ \\
\cline { 2 - 3 } & $\begin{array}{c}\text { NBS challenges } \\
(\mathrm{n}=14)\end{array}$ & $\begin{array}{c}\text { Focus on citizen and/or stakeholder } \\
\text { viewpoints of challenges on NBS } \\
\text { implementation }\end{array}$ \\
\hline \multirow{3}{*}{$\begin{array}{c}\text { Analysis of participation processes } \\
\text { on NBS (n=77) }\end{array}$} & \begin{tabular}{c} 
Drivers and motivations $(\mathrm{n}=14)$ \\
\cline { 2 - 3 }
\end{tabular} & $\begin{array}{c}\text { Analyzes drivers and motivation for } \\
\text { participation }\end{array}$ \\
\cline { 2 - 3 } & $\begin{array}{c}\text { Collaborative governance and } \\
\text { interactions } \\
(\mathrm{n}=17)\end{array}$ & $\begin{array}{c}\text { Analyzes methods, tools, or frameworks for } \\
\text { participation }\end{array}$ \\
\cline { 2 - 3 } & $\begin{array}{c}\text { Analyzes participation in terms of } \\
\text { governance and existing interactions }\end{array}$ \\
\cline { 2 - 3 } & $\begin{array}{c}\text { Challenges and opportunities } \\
(\mathrm{n}=20)\end{array}$ & $\begin{array}{c}\text { Analyzes challenges and opportunities } \\
\text { presented in the participatory process }\end{array}$ \\
\hline
\end{tabular}

\footnotetext{
Analysis of perceptions, preferences and perspectives
}

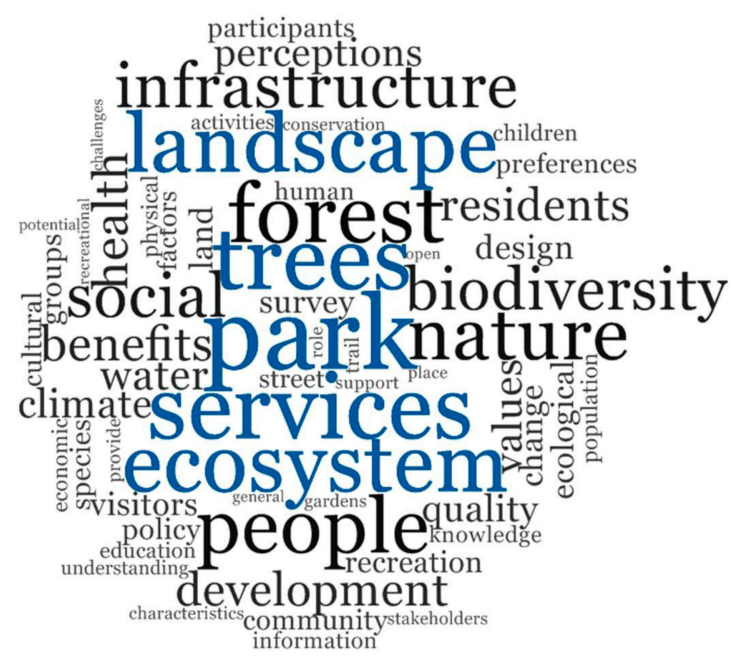

\section{Analysis of participation} processes

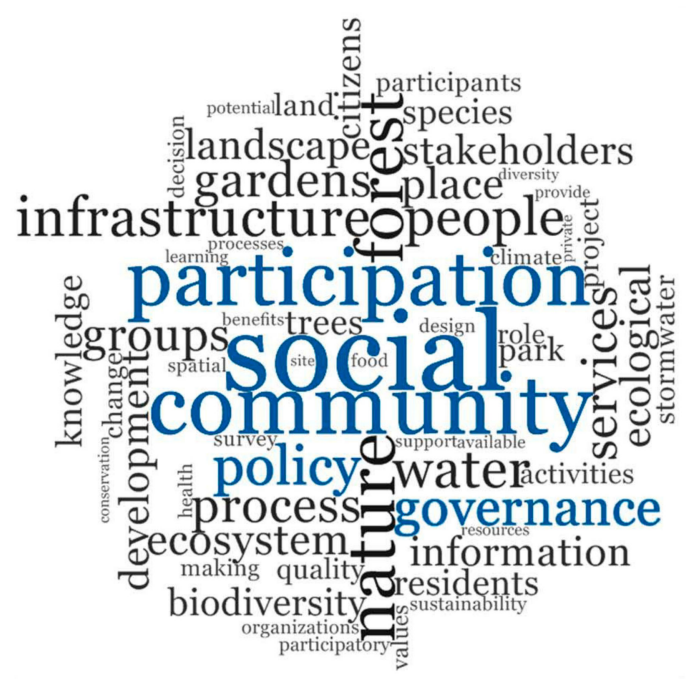

Figure 6. Word cloud arranged by area from the selected 142 papers.

\subsection{Citizens' and Stakeholders' Perceptions, Preferences, and Perspectives}

NBS effective governance and accuracy establishment increasingly require public input, and urban planners and policymakers are progressively aware of the need to take the perceptions and experiences into consideration. Understanding stakeholders' perceptions of, and preferences for green spaces and engaging them in the planning process can potentially bring benefits to residents and urban planners [23,26-28]. In addition to this understanding, considering the perceptions and preferences of citizens is seen as a first step in promoting and facilitating effective citizen participation and governance. 


\subsubsection{Perceived Benefits and Costs}

\section{Perceptions of the Benefits}

The perceived benefits of NBS are related to the ecosystem services (ES) provided. Some researchers have used an ES framework to create a more common language for the valuation of various benefits that NBS can provide $[29,30]$. The identification of perceived ES can provide guidelines and practical advice on urban design and management actions; mapping them is becoming a key tool for guiding decision-making [29]. The mapped perceptions enable the localization of the most highly valued ecosystems in a landscape and allow for identification of critical focal areas for ES management. Visual methods (photomontages) have also been shown useful to investigate residents' perceptions [31].

Table 2 presents the main benefits perceived by citizens and stakeholders according to the selected articles.

Table 2. The mainly perceived benefits of NBS by citizens and stakeholders as presented in the selected publications.

\begin{tabular}{|c|c|c|}
\hline Percei & ved Benefits $(n=34)$ & Authors \\
\hline \multirow{5}{*}{$\begin{array}{l}\text { Social Benefits } \\
\quad(n=27)\end{array}$} & $\begin{array}{l}\text { Aesthetics, scenic views and proximity } \\
\text { to nature }(\mathrm{n}=13)\end{array}$ & $\begin{array}{l}\text { Coles and Bussey } 2000 \text { [11]; Huang } 2014 \text { [32]; Barau } 2015 \\
\text { [33]; Buchel and Frantzeskaki } 2015 \text { [29]; } \\
\text { Conedera et al. } 2015 \text { [34]; Qiu and Nielsen 2015 [35]; } \\
\text { Rupprecht et al. } 2015 \text { [36]; Larson et al. } 2016 \text { [37]; } \\
\text { Ives et al. 2017 [38]; Korpilo et al. 2018 [39]; } \\
\text { Panagopoulos et al. } 2018 \text { [40]; Campbell-Arvai } 2019 \text { [28]; } \\
\text { Guenat et al. } 2019 \text { [41]. }\end{array}$ \\
\hline & Quality of life $(n=4)$ & $\begin{array}{l}\text { Sanesi and Chiarello } 2006 \text { [22]; Conedera et al. } 2015 \text { [36]; } \\
\text { Panagopoulos et al. } 2018 \text { [40]; Gwedla and Shackleton } \\
2019 \text { [42]. }\end{array}$ \\
\hline & Physical and mental well-being $(n=12)$ & $\begin{array}{l}\text { Coles and Bussey } 2000 \text { [11]; Peckham et al. } 2013 \text { [43]; } \\
\text { Buchel and Frantzeskaki 2015 [29]; Yen et al. } 2016 \text { [44]; } \\
\text { Faivre et al. } 2017 \text { [45]; Duan et al. } 2018 \text { [46]; } \\
\text { Keith et al. } 2018 \text { [27]; Nath et al. } 2018 \text { [47]; } \\
\text { Panagopoulos et al. } 2018 \text { [40]; Zwierzchowska et al. 2018 } \\
\text { [48]; Campbell-Arvai } 2019 \text { [28]; Gashu et al. } 2020 \text { [49]. }\end{array}$ \\
\hline & Sociocultural $(n=6)$ & $\begin{array}{c}\text { Huang } 2014 \text { [32]; Barau } 2015 \text { [33]; Buchel and } \\
\text { Frantzeskaki 2015 [29]; Conedera et al. } 2015 \text { [34]; } \\
\text { Zwierzchowska et al. 2018 [48]; Gashu et al. } 2020 \text { [49]. }\end{array}$ \\
\hline & Recreational and exercise $(n=10)$ & $\begin{array}{l}\text { Popoola and Ajewole } 2001 \text { [21]; Barnhill and Smardon } \\
\text { 2012 [26]; Buchel and Frantzeskaki 2015 [29]; } \\
\text { Giannakis et al. } 2016 \text { [50]; Larson et al. 2016 [37]; } \\
\text { Yen et al. } 2016 \text { [44]; Ives et al. 2017 [38]; Keith et al. 2018 } \\
\text { [27]; Meyer and Schulz } 2018 \text { [51]; Nath et al. } 2018 \text { [47]. }\end{array}$ \\
\hline \multirow{4}{*}{$\begin{array}{l}\text { Environmental Benefits } \\
\qquad(\mathrm{n}=21)\end{array}$} & Biodiversity and wildlife $(n=9)$ & $\begin{array}{l}\text { Peckham et al. } 2013 \text { [43]; Shwartz et al. } 2014 \text { [52]; } \\
\text { Rupprecht et al. } 2015 \text { [36]; Giannakis et al. } 2016 \text { [50]; } \\
\text { Meyer and Schulz } 2017 \text { [51]; Korpilo et al. } 2018 \text { [39]; } \\
\text { Campbell-Arvai } 2019 \text { [28]; Wang et al. } 2019 \text { [53]. }\end{array}$ \\
\hline & Shade $(n=5)$ & $\begin{array}{c}\text { Conway and Yip } 2016 \text { [54]; Paul and Nagendra } 2017 \text { [55]; } \\
\text { Fernandes et al. } 2019 \text { [56]; Guenat et al. } 2019 \text { [41]; } \\
\text { Gwedla and Shackleton } 2019 \text { [42]. }\end{array}$ \\
\hline & $\begin{array}{l}\text { Better air quality and climate regulation } \\
\qquad(\mathrm{n}=13)\end{array}$ & $\begin{array}{l}\text { Sanesi and Chiarello [22]; Peckham et al. } 2013 \text { [43]; } \\
\text { Buchel and Frantzeskaki 2015 [29]; Rupprecht et al. } 2015 \\
\text { [36]; Conway and Yip 2016 [54]; Giannakis et al. } 2016 \\
\text { [50]; Yen et al. 2016 [44]; Faivre et al. } 2017 \text { [45]; Paul and } \\
\text { Nagendra 2017 [55]; Duan et al. } 2018 \text { [46]; } \\
\text { Fernandes et al. } 2019 \text { [56]; Guenat et al. } 2019 \text { [41]; Miller } \\
\text { and Montalto 2019 [30]. }\end{array}$ \\
\hline & Water runoff mitigation $(\mathrm{n}=3)$ & $\begin{array}{l}\text { Barnhill and Smardon } 2012 \text { [26]; Paul and Nagendra } 2017 \\
\text { [55]; Miller and Montalto } 2019 \text { [30]. }\end{array}$ \\
\hline \multirow{3}{*}{$\begin{array}{l}\text { Economic Benefits }(\mathrm{n}= \\
\text { 8) }\end{array}$} & $\begin{array}{l}\text { Food provision } \\
\qquad(\mathrm{n}=3)\end{array}$ & $\begin{array}{c}\text { Barau } 2015 \text { [33]; Guenat et al. } 2019 \text { [41]; Gwedla and } \\
\text { Shackleton } 2019 \text { [42]. }\end{array}$ \\
\hline & $\begin{array}{l}\text { Wood provision } \\
\qquad(\mathrm{n}=2)\end{array}$ & $\begin{array}{l}\text { Popoola and Ajewole } 2001 \text { [21]; Meyer and Schulz } 2017 \\
\text { [51]. }\end{array}$ \\
\hline & Increase in property value $(n=3)$ & $\begin{array}{c}\text { Jim and Chen } 2006 \text { [23]; Yen et al. } 2016 \text { [44]; } \\
\text { Panagopoulos et al. } 2018 \text { [40]. }\end{array}$ \\
\hline
\end{tabular}


Perception of the Risks That Can Cause Costs/Disservices

Compared to ecosystem services, fewer studies have considered ecosystem disservices. An understanding of perceived risks among NBS, by citizens and stakeholders, is fundamental for their effective planning, implementation, and management [54]. Table 3 presents the main threats referred to in the screened research papers.

Table 3. The mainly perceived risks of NBS by citizens and stakeholders as presented in the selected publications.

\begin{tabular}{ll}
\hline \multicolumn{1}{c}{ Perceived Risks $(\mathbf{n}=\mathbf{9})$} & \multicolumn{1}{c}{ Authors } \\
\hline Danger (e.g., crime and vandalism) $(\mathrm{n}=6)$ & $\begin{array}{l}\text { Sanesi and Chiarello 2006 [22]; Ostoić et al. 2017 [57]; Keith et al. } \\
\text { 2018 [27]; Campbell-Arvai 2019 [28]; Fernandes et al. 2019 [56]; } \\
\text { Gwedla and Shackleton [42]. }\end{array}$ \\
\hline Dirtiness (e.g., leaves in autumn or bird excrement) $(\mathrm{n}=4)$ & $\begin{array}{l}\text { Conway and Yip 2016 [54]; Ostoić et al. 2017 [57]; Fernandes et al. } \\
\text { 2019 [56]; Gwedla and Shackleton 2019 [42]. }\end{array}$ \\
\hline Attraction of unwanted animals/insects $(\mathrm{n}=3)$ & $\begin{array}{l}\text { Jim and Chen 2006 [23]; Conway and Yip 2016 [54]; } \\
\text { Campbell-Arvai 2019 [28]. }\end{array}$ \\
\hline Limited Access/Environmental injustice $(\mathrm{n}=2)$ & Ostoić et al. 2017 [57]; Keith et al. 2018 [27]. \\
\hline Damage (e.g., person, property) $(\mathrm{n}=2)$ & Conway and Yip 2016 [54]; Campbell-Arvai 2019 [28]. \\
\hline Allergies $(\mathrm{n}=1)$ & Gwedla and Shackleton 2019 [42]. \\
\hline Economic costs (e.g., construction and maintenance) $(\mathrm{n}=2)$ & Conway and Yip 2016 [54]; Campbell-Arvai 2019 [28]. \\
\hline Invasive species of plants $(\mathrm{n}=1)$ & Campbell-Arvai 2019 [28] \\
\hline $\begin{array}{l}\text { Contamination }(\mathrm{e} . \mathrm{g} ., \text { soil through chemicals and dirty } \\
\text { water use) }(\mathrm{n}=1)\end{array}$ & Guenat et al. 2019 [41]. \\
\hline
\end{tabular}

\subsubsection{Preferred Attributes for the Design of NBS}

Urban policy has failed to provide specific design guidance for NBS. Public perception surveys enabled urban planners to identify preferred green infrastructure attributes and use this information in their urban planning framework [58]. Table 4 shows the most mentioned characteristics and attributes preferred by citizens and stakeholders for NBS design according to the analyzed publications.

Table 4. The most relevant preferences for design of NBS reported by citizens and stakeholders, as presented in the selected publications.

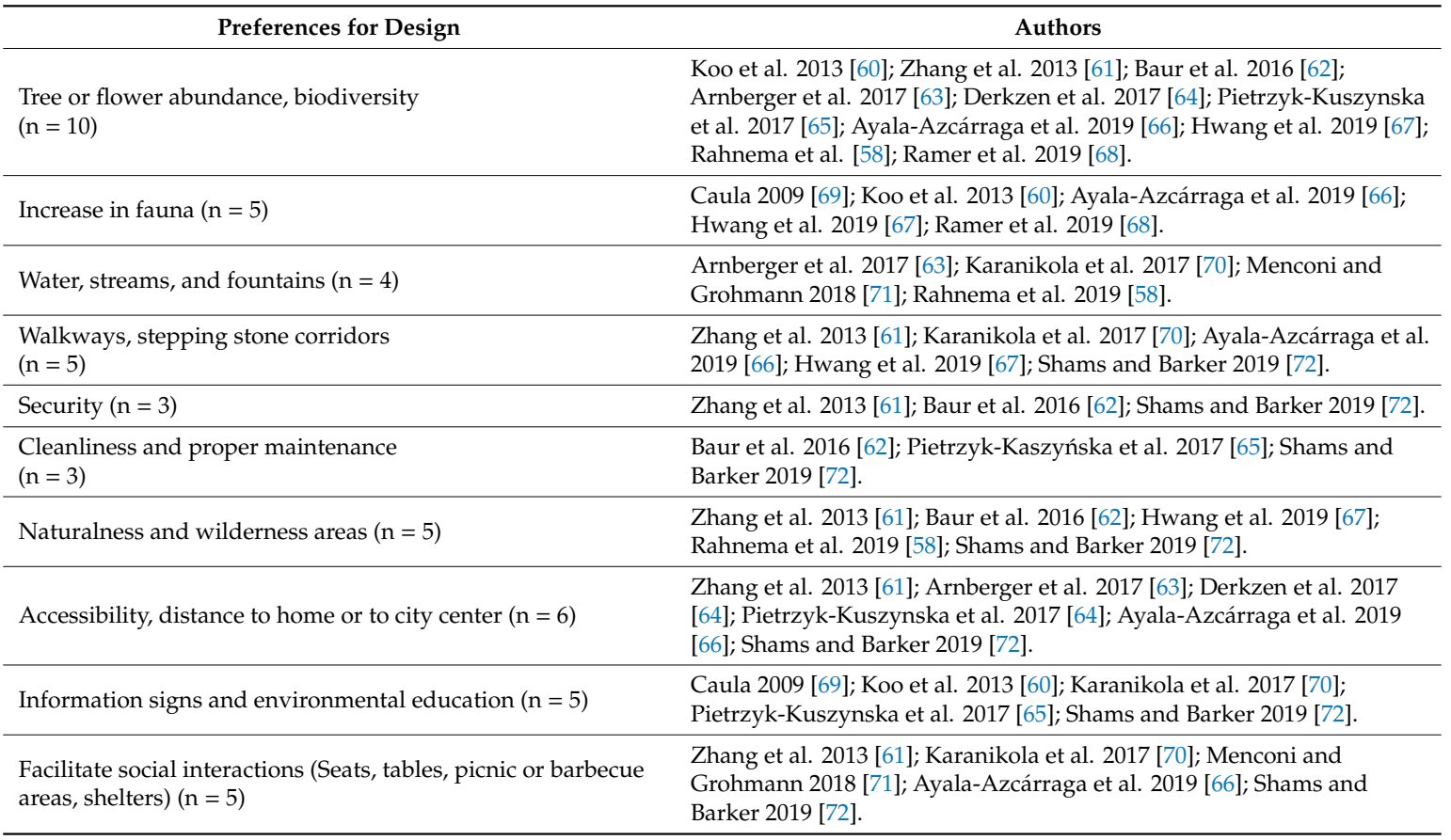


Table 4. Cont.

\begin{tabular}{ll}
\hline \multicolumn{1}{c}{ Preferences for Design } & \multicolumn{1}{c}{ Authors } \\
\hline Kids playground $(\mathrm{n}=3)$ & $\begin{array}{l}\text { Zhang et al. 2013 [61]; Menconi and Grohmananan 2018 [71]; } \\
\text { Ayala-Azcárraga et al. 2019 [66]. }\end{array}$ \\
\hline $\begin{array}{l}\text { Sports and recreational facilities }(\mathrm{n}=3) \\
\begin{array}{l}\text { Karanikola et al. 2017 [70]; Menconi and Grohmann 2018 [71]; Shams } \\
\text { and Barker 2019 [72]. }\end{array} \\
\begin{array}{l}\text { Connectivity to places of interest (e.g., parks, restaurants, } \\
\text { shops, monuments) }\end{array}\end{array}$ & Pietrzyk-Kuszynska et al. 2017 [65]; Shams and Barker 2019 [72]. \\
\hline \begin{tabular}{l} 
Green space into buildings $(\mathrm{n}=2)$ \\
\hline
\end{tabular} & Tsantopoulos et al. 2018 [59]; Xue et al. 2019 [3]. \\
\hline
\end{tabular}

Xue et al. [3] found that stakeholders are more likely to prefer biophilic design strategies that focus on immediate human spatial experience in buildings. Additionally, Tsantopoulos et al. [59] investigated public perceptions and attitudes toward GI on buildings and found that most of the citizens were keen to improve aesthetics through green roofs, trellises, or vertical gardens.

\subsubsection{Perspectives on the NBS Challenges}

The lack of knowledge and awareness literature that explores the citizens' and stakeholders' perspectives and perceptions regarding challenges for NBS. Table 5 shows the main challenges reported by citizens and stakeholders for the implementation and maintenance of NBS based on the selected publications.

Table 5. The main NBS challenges identified by citizens and stakeholders, as reported in the selected publications

\begin{tabular}{|c|c|}
\hline NBS challenges & Authors \\
\hline $\begin{array}{l}\text { Lack of knowledge and awareness about the } \\
\text { environmental problems and their possible solutions } \\
\text { and impacts }(n=8)\end{array}$ & $\begin{array}{l}\text { Lamichhane and Thapa } 2012 \text { [73]; Keeley et al. } 2013 \text { [74]; Hoyle } \\
\text { et al. } 2017 \text { [75]; Furlong et al. } 2018 \text { [76]; Khoshkar et al. } 2018 \text { [77]; } \\
\text { Onori et al. } 2018 \text { [78]; Girma 2019 [79]; } \\
\text { Molla and Mekonnen } 2019 \text { [80]. }\end{array}$ \\
\hline $\begin{array}{l}\text { Lack of evidence of the success and efficacy of the } \\
\text { solutions }(n=1)\end{array}$ & Kabisch et al. 2016 [14]. \\
\hline Lack of political support/guidance $(\mathrm{n}=8)$ & $\begin{array}{l}\text { Lamichhane and Thapa } 2012 \text { [73]; Keeley et al. } 2013 \text { [74]; } \\
\text { Zivojinovic and Wolfslehner } 2015 \text { [81]; Furlong et al. } 2018 \text { [76]; } \\
\text { Khoshkar et al. } 2018 \text { [77]; Girma 2019 [79]; Lähde and Marino } 2019 \\
\text { [82]; Molla and Mekonnen } 2019 \text { [80]. }\end{array}$ \\
\hline Financial constraints and lack of funding $(\mathrm{n}=8)$ & $\begin{array}{l}\text { Lamichhane and Thapa } 2012 \text { [73]; Keeley et al. } 2013 \text { [74]; Rall et al. } \\
2015 \text { [83]; Zivojinovic and Wolfslehner } 2015 \text { [81]; Furlong et al. } \\
2018 \text { [76]; Khoshkar et al. } 2018 \text { [77]; Di Marino et al. } 2019 \text { [84]; } \\
\text { Girma 2019 [79]. }\end{array}$ \\
\hline Lack of engagement due low social cohesion $(n=7)$ & $\begin{array}{l}\text { Lamichhane and Thapa } 2012 \text { [73]; Rall et al. } 2015 \text { [83]; Zivojinovic } \\
\text { and Wolfslehner } 2015 \text { [81]; Kabisch et al. } 2016 \text { [14]; Hoyle et al. } \\
2017 \text { [75]; Bissonnette et al. } 2018 \text { [85]; Girma } 2019 \text { [79]. }\end{array}$ \\
\hline $\begin{array}{l}\text { Lack of skilled personnel/technical and scientific } \\
\text { knowledge }(\mathrm{n}=3)\end{array}$ & $\begin{array}{l}\text { Keeley et al. 2013 [74]; Zivojinovic and Wolfslehner } 2015 \text { [81]; } \\
\text { Girma } 2019 \text { [79]. }\end{array}$ \\
\hline Maintenance and monitoring $(\mathrm{n}=4)$ & $\begin{array}{l}\text { Lamichhane and Thapa } 2012 \text { [73]; Rall et al. } 2015 \text { [83]; Keeley et al. } \\
2017 \text { [74]; Khoshkar et al. } 2018 \text { [77]. }\end{array}$ \\
\hline
\end{tabular}

Lack of knowledge and awareness, as well as political support, financial constraints, and lack of public engagement, are the most mentioned challenges. Lack of knowledge and awareness is responsible for negative views of trees and vegetation; it may result in limiting public support for urban green solutions, particularly on private land [76,80]. Vandalism may also explain low support for NBS [57]. Furthermore, the lack of awareness from municipal, regional and national government agencies about the benefits of such green solutions has affected budget al.ocation for their development [79]. Collaboration of nonprofit organizations and voluntary community groups and partnerships can raise funds for the development of those solutions [86]. 
According to Kabisch et al. [14], NBS need to be recognized and developed as proactive investments and supported as such in planning procedures; they should also be fostered in joint dialogues among policy, society, and science. To avoid the loss of desired project qualities and minimize the related conflicts of interests between the different stakeholders, municipalities in and around Stockholm have increased citizen participation and collaboration between planners and developers, as a way of overcoming the challenges faced with the implementation of NBS [77]. The results of this test were the minimization of conflicting interests between involved and affected actors, and the decrease of green quality management issues. According to Young [86], this type of initiative benefits from being launched early in an administration term, providing long-term advancement and protection of GI or NBS investments.

\subsection{Citizens' and Stakeholders' Participation in the Processes of NBS}

\subsubsection{Opportunities and Challenges Found in the NBS Practices}

Opportunities

As previously mentioned, citizen and stakeholder participation in NBS has been reported as crucial for the success of those solutions. Such participation usually involves people and organized groups that can influence the decision-making processes. In this section, firstly, we analyze the opportunities that emerge from actual community participation in NBS that were identified in the selected publications. Table 6 summarizes them.

Table 6. The opportunities for NBS that emerge from citizen and stakeholder participation, as reported in the selected publications.

\begin{tabular}{|c|c|}
\hline Opportunities $(\mathrm{n}=16)$ & Authors \\
\hline $\begin{array}{l}\text { Promote social cohesion (cooperative working, } \\
\text { mutual learning, and experience-sharing) }(\mathrm{n}=6)\end{array}$ & $\begin{array}{l}\text { Chou et al. } 2017 \text { [87]; Fors et al. } 2018 \text { [88]; Harper et al. } 2018 \text { [89]; } \\
\text { Kosová et al. } 2018 \text { [90]; Ugolini et al. } 2018 \text { [91]; Rolf et al. } 2019 \text { [92]. }\end{array}$ \\
\hline Add-value to urban natural and social capital $(\mathrm{n}=2)$ & Dennis and James 2016 [93]; Dennis and James 2016 [94]. \\
\hline Increase biodiversity $(\mathrm{n}=3)$ & $\begin{array}{c}\text { Mabelis and Maksymiuk } 2009 \text { [13]; Dennis and James } 2016 \text { [94]; } \\
\text { Fischer et al. 2019 [95]. }\end{array}$ \\
\hline $\begin{array}{l}\text { Contextualize functions with ecosystem services } \\
\qquad(\mathrm{n}=1)\end{array}$ & Dennis and James 2016 [93]. \\
\hline Develop initiatives of environmental education $(n=3)$ & $\begin{array}{l}\text { Moskell and Allred } 2013 \text { [96]; Chou et al. } 2017 \text { [87]; Fischer et al. } \\
2019 \text { [95]. }\end{array}$ \\
\hline $\begin{array}{l}\text { Intensify the public acceptability, confidence, } \\
\text { consciousness and sense of belonging }(\mathrm{n}=4)\end{array}$ & $\begin{array}{l}\text { Sipilä and Tyrväinen } 2005 \text { [12]; Fors et al. } 2018 \text { [88]; Gulsrud et al. } \\
\qquad 2018 \text { [97]; Rolf et al. } 2019 \text { [92]. }\end{array}$ \\
\hline $\begin{array}{l}\text { Influence social learning and innovation } \\
\qquad(\mathrm{n}=6)\end{array}$ & $\begin{array}{c}\text { Travaline et al. } 2015 \text { [98]; Dennis et al. 2016 [99]; Chou et al. } 2017 \\
\text { [87]; Gulsrud et al. } 2018 \text { [97]; Kosová et al. } 2018 \text { [90]; } \\
\text { Ugolini et al. 2018 [91]. }\end{array}$ \\
\hline Benefit from multifunctionality $(\mathrm{n}=2)$ & Belmeziti et al. 2018 [100]; Rolf et al. 2019 [92]. \\
\hline Connect people with nature $(n=3)$ & Chou et al. 2017 [87]; Gulsrud et al. 2018 [97]; Fors et al. 2018 [88]. \\
\hline $\begin{array}{l}\text { Establish long-term partnerships to attain funding } \\
\qquad(\mathrm{n}=1)\end{array}$ & Ugolini et al. 2018 [91]. \\
\hline Prevent conflicts $(n=2)$ & Sipilä and Tyrväinen 2005 [12]; Rolf et al. 2019 [92]. \\
\hline
\end{tabular}

Green infrastructure planning needs to rely on collaborative and participatory approaches to enhance ecosystem services at all scales [85]. The public involvement can play a fundamental role in enhancing the productivity of urban green spaces, increasing the value of ecosystem services. Stakeholder participation ensures identification of ES from the beginning and the links between them and greenspace components, helping urban planners and managers to improve the multifunctionality of solutions $[93,100]$. Work has been carried out which demonstrates that biodiversity increases proportionally to levels of user participation [94]. 
The different actors bring different forms of knowledge to the process. Brink and Wamsler [101] stressed the importance of collaboration between local government and citizens in order to address climate impacts more effectively. The concept of "biodiverse edible schools," that link food production and consumption with local biodiversity, presented by Fischer et al. [95], adopts a long-term engagement of stakeholders from various domains to improve healthy food and environmental education at the school. Participation is anticipated to produce better policies by encouraging the exchange of information and ideas and by promoting collaborative learning about problems and their potential solutions [90].

Partnerships with local actors, especially through community groups, can encourage trust, while facilitating ecosystem stewardship and social learning as critical factors for socioecological resilience [97].

\section{Challenges}

Several barriers hinder public participation; these mostly include challenges related to the cultural domain. The most typical problem is that of poor social mobilization, reflected in the fact that urban residents often perceive GI solution stewardship as the responsibility of government (either local, state, or federal), not their own [96]. Table 7 presents a resume of the main identified challenges that have prevented stakeholders and citizens from being engaged and participating in NBS projects.

Table 7. The challenges faced by citizens and stakeholders that prevent their participation in processes of NBS, identified in the selected publications

\begin{tabular}{cc}
\hline Challenges $(\mathbf{n}=\mathbf{1 0})$ & Authors \\
\hline $\begin{array}{c}\text { Deal with conflicting points of view and interests } \\
(\mathrm{n}=3)\end{array}$ & $\begin{array}{c}\text { Sipilä and Tyrväinen 2005 [12]; Cousins 2017 [102]; } \\
\text { Ugolini et al. 2018 [91]. }\end{array}$ \\
\hline $\begin{array}{c}\text { Understand the hierarchies of institutions and } \\
\text { bureaucracies }(\mathrm{n}=5)\end{array}$ & $\begin{array}{c}\text { Mattijssen et al. 2017 [103]; Mensah et al. 2017 [104]; Gulsrud et al. } \\
\text { 2018 [97]; Liu and Jensen 2018 [105]; Ugolini et al. 2018 [91]. }\end{array}$ \\
\hline $\begin{array}{c}\text { Overtake the lack of political support } \\
(\mathrm{n}=2)\end{array}$ & Gulsrud et al. 2018 [97]; Liu and Jensen 2018 [105]. \\
\hline $\begin{array}{c}\text { Feel the involvement as being time consuming and } \\
\text { expensive }(\mathrm{n}=3)\end{array}$ & $\begin{array}{c}\text { Sipilä and Tyrväinen 2005 [12]; Mabelis and Maksymiuk 2009 [13]; } \\
\text { Travaline et al. 2015 [98]. }\end{array}$ \\
\hline $\begin{array}{c}\text { Overcome the poor flow of information and social } \\
\text { mobilization ( }=2)\end{array}$ & Moskell and Allred 2013 [96]; Mensah et al. 2017 [104]. \\
\hline $\begin{array}{c}\text { Maintain continuity of the collaboration } \\
(\mathrm{n}=1)\end{array}$ & Mattijssen et al. 2017 [103]. \\
\hline
\end{tabular}

Sipilä and Tyrväinen [12] found that participatory approaches are more demanding with respect to time and resources than conventional planning. The same authors mentioned other difficulties: the type of people interested in participating (with limited representativeness); the low number of participants; increased conflict between opposing stakeholders; and too-high expectations from participants, resulting in disappointment over compromise.

To avoid the challenges related to divergence of interests among stakeholders, Ugolini et al. [91] indicated the need for a "common language"-i.e., "speaking green"—which may accommodate diverse priorities and concerns. Early dialogue and partnership with citizens and stakeholders provides the opportunity to identify common goals [77].

Usually, the lack of political support is related to low awareness of politicians and key administrators. Bureaucracy is a challenge encountered in collaborations with public administrations [91]; it can also have a hindering or discouraging impact on the activities of citizens [103].

Yamaki [106] suggested that social media would be essential to overcoming some participation challenges related with the exchange of information and knowledge or poor social mobilization. 
An important challenge that remains is to achieve continuity in the engagement of citizens; in this regard, Mattijssen et al. [103] highlight the importance of attracting new volunteers over time to maintain a critical mass.

\subsubsection{Identified Drivers/Motivations for Public Participation}

Looking at the selected articles, the main motivations and drivers for citizen and stakeholder participation on the NBS can be organized into three reasons as summarized in Table 8.

Table 8. The motivations and related drivers invoked by citizens and stakeholders to participate in process of NBS, as identified in the selected publications.

\begin{tabular}{|c|c|c|}
\hline \multicolumn{2}{|c|}{ Motivations/Drivers } & Authors \\
\hline \multirow{2}{*}{$\begin{array}{l}\text { Environmental } \\
\qquad(n=7)\end{array}$} & $\begin{array}{l}\text { Environment protection and } \\
\text { contribution to sustainability } \\
\qquad(\mathrm{n}=5)\end{array}$ & $\begin{array}{l}\text { Asah and Blahna } 2012 \text { [107]; Shan } 2012 \\
\text { [108]; Zare et al. } 2015 \text { [109]; Chelleri et al. } \\
\text { 2016 [25]; Beery et al. } 2018 \text { [110]. }\end{array}$ \\
\hline & $\begin{array}{l}\text { Characteristics of the physical } \\
\text { environment }(\mathrm{n}=2)\end{array}$ & Fors 2019 [111]; Murphy 2019 [112]. \\
\hline \multirow{3}{*}{$\begin{array}{l}\text { Communal } \\
(\mathrm{n}=8)\end{array}$} & $\begin{array}{l}\text { Protect the community/improve } \\
\text { collective health }(\mathrm{n}=2)\end{array}$ & Zare et al. 2015 [109]; Beery et al. 2018 [110]. \\
\hline & $\begin{array}{l}\text { Promote social interactions } \\
\qquad(\mathrm{n}=2)\end{array}$ & $\begin{array}{l}\text { Asah and Blahna } 2012 \text { [107]; } \\
\text { Zare et al. } 2015 \text { [109]. }\end{array}$ \\
\hline & $\begin{array}{l}\text { Bring neighbors to participate and be } \\
\text { part of the experiences }(n=5)\end{array}$ & $\begin{array}{l}\text { Green et al. } 2012 \text { [113]; Lewis et al. } 2018 \\
\text { [114]; Lieberherr and Green } 2018 \text { [115]; Lim } \\
2018 \text { [116]; Fors } 2019 \text { [111]. }\end{array}$ \\
\hline \multirow{4}{*}{$\begin{array}{l}\text { Personal } \\
(n=8)\end{array}$} & $\begin{array}{l}\text { Possibility to learn from and experience } \\
\text { environmentally friend solutions }(n=3)\end{array}$ & $\begin{array}{l}\text { Asah and Blahna } 2012 \text { [107]; Chelleri et al. } \\
2016 \text { [25]; Lewis et al. } 2018 \text { [114]. }\end{array}$ \\
\hline & Interest in gardening $(\mathrm{n}=2)$ & Fors 2019 [111]; Petrovic et al. 2019 [117]. \\
\hline & Sense of place and attachment $(n=3)$ & $\begin{array}{l}\text { Murphy } 2019 \text { [112]; Petrovic et al. } 2019 \\
\text { [117]; Romolini } 2019 \text { [118]. }\end{array}$ \\
\hline & $\begin{array}{l}\text { Proximity to disturbance and effects on } \\
\text { residential properties }(n=2)\end{array}$ & Hunter et al. 2011 [119]; Fors 2019 [111]. \\
\hline
\end{tabular}

Civic consciousness has been increasing; in recent years, more and more people started to display a positive attitude and strong willingness toward participation on NBS $[108,110]$. Some citizens are motivated by the prospect of improving their physical and/or mental health, and others are only moved by collective purposes (e.g., building friendly relationships) [109]. Usually, the degree of engagement is directly connected to the individual's proximity to the disturbance [119], and some types of environment are more difficult for people to involve in [111].

Some authors have found that most of the citizens are willing to participate in NBS planning, implementation, and management to ensure social, and environmental benefits, e.g., [25,108]; some found further that citizens were willing to contribute financially, e.g., [64,69]. Zare et al. [109] found that people were more willing to participate as a "membership in a public conservation committee" than in practical management activities. According to Green et al. [113], for example, to engage or encourage citizens as stormwater managers, we must go beyond the technical aspects and invest in social factors to motivate behavioral change. It is also acknowledged that, as participants share their experiences, neighbors become more willing to trust in the program of NBS $[113,116]$.

Green infrastructure solutions have contributed to enhancing ecosystem governance and increasing a sense of place, especially in relation to urban gardens and urban agricultural areas (where residents directly participate in their management, maintenance, and monitoring) [117]. Romolini [118] found a positive relationship between public interest in collaborate and place attachment, i.e., individuals' psychological and emotional connection to urban green spaces precedes their involvement in processes of NBS. 


\subsubsection{Methods, Tools, and Frameworks}

A range of methods and tools have been used to engage stakeholders and citizens in urban GI and NBS. Table 9 displays the various methods and tools used in the selected publications of this literature review.

Table 9. Methods/tools used in the selected publications to involve citizens and stakeholders as participants on NBS

\begin{tabular}{|c|c|c|}
\hline \multicolumn{2}{|c|}{ Participation Methods/Tools } & Authors \\
\hline \multicolumn{2}{|c|}{ Social media $(\mathrm{n}=3)$} & $\begin{array}{l}\text { Afzalan and Muller } 2014 \text { [120]; Guerrero et al. } 2016 \\
\text { [121]; Yamaki 2016 [106]. }\end{array}$ \\
\hline \multicolumn{2}{|c|}{ E-Tools/virtual tool $(n=2)$} & Shwartz et al. 2013 [122]; Møller et al. 2019 [123]. \\
\hline \multirow{4}{*}{ GIS-based tools $(n=8)$} & PPGIS & $\begin{array}{c}\text { Janse and Konijnendijk } 2007 \text { [124]; Hawthorne et al. } \\
2015 \text { [125]; Raymond et al. 2016 [126]; } \\
\text { Rall et al. } 2019 \text { [127]. }\end{array}$ \\
\hline & SolVES & Sun et al. 2019 [128]. \\
\hline & VGI & Guerrero et al. 2016 [121]; Møller et al. 2019 [123]. \\
\hline & $3 \mathrm{D}$ visualization & Neuenschwander et al. 2014 [129]. \\
\hline \multicolumn{2}{|c|}{ Focus Group $(n=3)$} & $\begin{array}{l}\text { Nilsson et al. } 2007 \text { [130]; Kangas et al. } 2014 \text { [131]; } \\
\text { Sturiable et al. } 2018 \text { [132]. }\end{array}$ \\
\hline \multicolumn{2}{|c|}{ Workshop $(\mathrm{n}=4)$} & $\begin{array}{l}\text { Janse and Konijnendijk } 2007 \text { [124]; Bellamy et al. } \\
2017 \text { [133]; Assmuth et al. } 2017 \text { [134]; van der Jagt } \\
\text { et al. } 2019 \text { [135]. }\end{array}$ \\
\hline \multicolumn{2}{|c|}{ Questionnaire/Survey/Q methodology $(\mathrm{n}=10)$} & $\begin{array}{l}\text { Janse and Konijnendijk } 2007 \text { [124]; Kangas et al. } 2014 \\
\text { [131]; Hawthorne et al. } 2015 \text { [125]; Lindemann and } \\
\text { Briege } 2016 \text { [136]; Raymond et al. 2016 [126]; Sun and } \\
\text { Hall } 2016 \text { [137]; Jayasooriya et al. } 2019 \text { [138]; } \\
\text { Lafortezza and Giannico } 2019 \text { [139]; Møller et al. } \\
\text { 2019 [123]; Rall et al. } 2019 \text { [127]. }\end{array}$ \\
\hline \multicolumn{2}{|c|}{ Interviews $(\mathrm{n}=4)$} & $\begin{array}{c}\text { Nordström et al. } 2010 \text { [140]; Kangas et al. } 2014 \text { [131]; } \\
\text { Beumer and Martens } 2015 \text { [141]; Sturiable and } \\
\text { Scuderi } 2018 \text { [132]. }\end{array}$ \\
\hline \multicolumn{2}{|c|}{ Meetings $(\mathrm{n}=5)$} & $\begin{array}{c}\text { Nordström et al. } 2010 \text { [140]; Afzalan and Muller } 2014 \\
\text { [120]; O'Donnell et al. } 2018 \text { [142]; Sturiable and } \\
\text { Scuderi } 2018 \text { [132]; } \\
\text { Lafortezza and Giannico 2019 [139]. }\end{array}$ \\
\hline \multicolumn{2}{|c|}{ Visual methods $(\mathrm{n}=4)$} & $\begin{array}{l}\text { Qiu et al. } 2013 \text { [143]; Lindemann and Briege } 2016 \\
\text { [136]; Rink and Arndt } 2016 \text { [31]; Sun et al. } 2019 \text { [128]. }\end{array}$ \\
\hline \multicolumn{2}{|c|}{ Learning Alliances $(\mathrm{n}=2)$} & $\begin{array}{l}\text { O'Donnell et al. } 2018 \text { [142]; } \\
\text { van der Jagt et al. } 2019 \text { [135] }\end{array}$ \\
\hline \multicolumn{2}{|c|}{ Living Labs $(\mathrm{n}=3)$} & $\begin{array}{l}\text { Bellamy et al. } 2017 \text { [133]; Lafortezza and Giannico } \\
2019 \text { [139]; van der Jagt et al. } 2019 \text { [135] }\end{array}$ \\
\hline
\end{tabular}

Questionnaires and surveys have been the most common tool used in the participatory processes (Table 9). The reason may lie in the fact that these tools are reproducible, comparable, and easy to implement for the collection of citizens' perceptions, preferences, and viewpoints, being at the same time useful to support NBS planning and the decision-making process. Some authors used Q-methodology that is based on a limited set of perceptions and viewpoints that people have on a certain topic, to provide information (similarities and differences) within a range of perceptions and viewpoints [131]. Visual methods (e.g., photo-realistic visualizations) have been linked to questionnaires and surveys to help in the design process $[31,136]$.

Methods including geographic information systems have been increasing due to the incorporation of socio-spatial information in strategic green space planning. An example is public participation geographic information systems (PPGIS) [127], that enhance citizens or stakeholders to identify 
locations on a map of various aspects such as perceptions, preferences, or values, and particularly associate them with ecosystem services.

E-tools have received attention because of their potential to connect government and citizens and facilitate interaction between them. Møller et al. [123] studied three map-based e-tools, i.e., users share information on digital maps (so-called Volunteered Geographic Information (VGI)).

Social media platforms have increasingly been used as a fundamental tool to facilitate collaboration and interactions among stakeholders on NBS, enhancing social learning that fosters social capital, resource mobilizations, and consensus building [106].

Other methods have shown the potential of participatory processes, such as workshops, focus groups, and meetings. In a workshop, Assmuth et al. [134] used an innovative and "out-of-the-box" method of opinion elicitation, a role chair session (where experts were asked to step into the shoes of other population groups, based on their prior knowledge to interpret the positions of the groups while sitting in a chair for the respective group addressed).

Some of the selected publications presented a structured methodological framework for citizen or stakeholder participation in NBS, including specific methods and steps to follow. Further frameworks have been developed to map priority areas for green infrastructure [133] and to integrate stakeholders' perceptions and knowledge regarding this important component for urban landscape $[132,137,139]$ and add remotely-sensed data, such as high-resolution satellite images and Laser Imaging Detection and Ranging (LiDAR) [139]. In this context, Beumer and Martens [141] speak about "BIMBY (Biodiversity in my (back) yard)," an indicator framework for assessing biodiversity in domestic gardens in the way that it explicitly combines ecological factors, cultural elements and citizen's preferences. Other authors used platforms for the mobilization and co-production of knowledge at different scales, known as Learning Alliances (LA) [135,142] and Living Labs (LL) [133,135,139], and combine a whole set of participation tools, such as workshops or focus groups, and use them structurally through the process, concerning the engaged group, time, scale, aim, and the expected outcome.

\subsubsection{Collaborative Governance and Actors' Interactions Through the Decision-Making Process}

In collaborative urban planning, one of the key questions is how the different actors interact and how their input can be integrated into planning and decision-making process. Looking at the participatory processes on the different NBS, diverse forms of collaborative governance and interaction between actors have been identified; these are summarized in Table 10.

Table 10. Type of collaborative governance and actors' interactions through the process of NBS, as identified in the selected publications.

\begin{tabular}{cl}
\hline \multicolumn{1}{c}{ Collaborative Governance } & \multicolumn{1}{c}{ Authors } \\
\hline $\begin{array}{c}\text { Top-down approach and a central-government } \\
\text { decision process }(\mathrm{n}=6)\end{array}$ & $\begin{array}{l}\text { Rosol 2010 [144]; Faehnle et al. 2014 [145]; Skandrani et al. } \\
\text { 2015 [146]; Gasperi et al. 2016 [147]; Kronenberg et al. 2016 }\end{array}$ \\
& [148]; Shifflet et al. 2019 [149]. \\
\hline \multirow{2}{*}{ Bottom-up and citizen-led approaches $(\mathrm{n}=6)$} & $\begin{array}{l}\text { Rosol 2010 [144]; Cvejić et al. 2015 [150]; Skandrani et al. } \\
\text { 2015 [146]; Gasperi et al. 2016 [147]; Jerome 2017 [151]; van } \\
\text { der Jagt et al. 2017 [152]. }\end{array}$ \\
\hline \multirow{2}{*}{ Public-private interactions $(\mathrm{n}=5)$} & Young 2011 [86]; Milanovič and Foški 2015 [153]; Brink and \\
& Wamsler 2016 [31]; Simić et al. 2017 [154]; \\
& Buijs et al. 2019 [155]. \\
\hline \multirow{2}{*}{ Cross-sectoral partnerships $(\mathrm{n}=4)$} & Ugolini et al. 2015 [156]; Schifman et al. 2017 [157]; van der \\
& Jagt 2017 [152]; Frantzeskaki 2019 [158]. \\
\hline
\end{tabular}

Top-down approaches are usually led and supported by national, regional or local governments or other public institutions and green spaces are usually managed in a centralized manner, with low (or very low) levels of civic involvement $[147,148]$. Gasperi et al. [147] exposed not participatory top-down projects that resulted in unsuccessful initiatives, as they did not respond to community expectations and needs. 
Bottom-up and citizen-led approaches are usually driven by citizens or non-governmental actors, enhancing strong local community engagement on green infrastructure planning and management. Although these approaches can strongly depend on the support of the local government [147]. Many examples of community-led systems are urban gardens or urban agriculture [147].

On urban vegetation governance, there have been efforts to move from top-down planning and decision-making towards involving a broad range of non-governmental actors and recognizing local needs and expertise based on citizens' everyday experiences, to overcome barriers and foster innovation [145]. Schifman et al. [157] developed a framework (FrASH) to integrate networks of stakeholders and organizations into GI projects to enhance multifunctionality. This work is centered on the combination of inputs from organizations to reach collaborative decision-making.

Recent research examines and proposes other multi-stakeholder governance processes such as public-private interactions [155] and cross-sectoral partnerships [156]. Public-private partnerships are encouraged as they carry top-down guidelines with the contributions of private sector. Cross-sectoral partnerships require the reconfiguration of the relationships between state, market actors, civil society, and science. Ugolini et al. [156] pointed out that the involvement of experts from academia has been a great benefit, since academics can offer scientific knowledge and innovation, research experience, expertise, and problem solutions.

\section{Discussion}

The selection of publications allowed us to identify two main areas of research with almost equal relevance: (a) publications analyzing the perceptions, preferences and perspectives of citizens and stakeholders in order to engage them into participation by uncovering their cognitive image of NBS as prior action and (b) publications that analyze the participatory process itself. In the first area, the benefits and costs sought by those involved or affected by the configuration of NBS emerge as the principal subarea of research. In the second area, the research on methods and tools is predominant. The contrast between the two domains becomes visible through analyzing the most common words as presented in the word cloud (see Figure 6): park, spaces, trees, landscape, and nature, for the first area, versus management, planning, community, governance and participation, for the second area.

Among the benefits perceived by citizens and stakeholders from NBS, the majority of the literature addresses the social benefits, closely followed by the environmental benefits and only a few studies look at the economic benefits in order to analyze various themes. This bias that favors the social and environmental benefits is also referred to by Parker and Baro [9]. Concerning the social benefits, studies stood out that deal with aesthetics, scenic views, and proximity to nature, followed by studies addressing physical and mental well-being and recreation/exercise. Studies on the environmental benefits focus on better air quality and climate regulation, as well as on biodiversity and wildlife. Surprisingly, only a small number of publications $(n=4)$ dealt with the benefits from NBS to quality of life in cities.

Regarding the citizens' and stakeholders' perceived risks of NBS that can generate costs/disservices, we observe that the number of publications is significantly inferior to the one dealing with the perceived benefits. The publications dealing with the risks of citizen and stakeholder participation are distributed diffusely across 10 categories, which signals an absence of a comprehensive understanding of the costs associated with NBS. The tendency of the literature to focus on the benefits, avoiding looking at the risks, has been pointed out by those skeptical about the participatory approaches to NBS. Fors et al. [20] highlighted that there is a rhetoric around public participation, as they failed to find empirical evidence of a convergence between expected and achieved benefits from the involvement of citizens and stakeholders and its effects for the quality of the implemented solutions. It is worth mentioning that, among the identified risks in the selected publications, all categories with more than one publication had at least one article in 2019 (with the exception of environmental justice). The risk related to environmental injustice has only three publications, none of them in 2019, which seems to indicate that this subtopic has been receiving scant attention from the researchers. This observation 
deserves consideration, as one of the objectives of NBS should be to reduce social injustices. The small number of studies dealing with how NBS impacts on social justice may lie in the fact that it often is difficult to bring those with low income into the participation process. Zuniga-Teran and Gerlak [17] suggested two main reason for this: (a) such families may not be able to afford using their time in tasks of social engagement and (b) the absence or dismantling of certain NGOs that may represent this group.

The preferences for attributes identified in the surveyed literature, as reported by citizens and stakeholders and related to the design of NBS, showed a spread over 14 categories; these highlight the diversity of interests involved in any process of participation. The abundance of trees or flowers and the increase of urban biodiversity is clearly the attribute most preferred by society, as reported in the selected publications. Fors et al. [20] also found that one of the factors that make users of green spaces participate is the desire to have a higher area covered with trees or healthier trees. Interestingly, the citizens' and stakeholders' preferences for design that take into consideration the natural environment and wilderness areas only appear in publications of 2019. This may be a sign of an increasing awareness in the populace of the need to respect ecological balances and plan the use of land according to environmentally-sustainable rules.

Looking at the second area of research identified in this review: the participation process in NBS and, in particular, the opportunities this process brings, a pulverization of opportunities is identified; we organized these into 11 categories. The most referred opportunities derived from the implementation of participation processes were the increase of social cohesion, followed by the influence of such participation for social learning and the identification of innovative solutions. Surprisingly, the opportunity to prevent conflicts was scarcity addressed in the literature (only two publications; see Table 6), being acknowledged as one of the limitations for successfully implement NBS, e.g., [10,19]. Citizens and stakeholders report it as one of the challenges emerging from the participation processes; however, the issue is only analyzed in three articles (see Table 7).

Other challenges that need to be overpass seem to capture more the attention of the researchers, namely, the difficulty of the participants in NBS processes to understand how public entities are organized and how to deal with bureaucracies. In contrast with Sarabi et al. [10] that identified nine publications dealing with the inadequacy of financial resources, this challenge is not reported in the selected publication included in this work when associated to the implementation of NBS (Table 7), appearing only in eight publications when perceptions are assessed (see Table 5). Only a few works looked at the challenge related to time spent on participation processes as a drawback (since citizens with low income may find it difficult to devote time to this type of process, which implies that those more vulnerable in society may find their needs overlooked). This suggests that the implementation of NBS is not contributing yet to bring social inclusiveness. This appears as one of the major gaps in the literature and one of the aspects in which the intention of involving all the layers of the society has been failing.

Contrasting the challenges identified after the implementation of NBS processes (Table 7) with those that were expected (Table 5), it is observed that almost completely different lists of challenges (with the exception of lack of political support) are derived. This divergence in the identified challenges signals that expectations regarding the implementation of NBS are detached from the real challenges faced through their implementation. Fors et al. [20] have pointed out how concepts in theory can be distant from the ones supported by empirical evidence. They called for the "defeat of generalizations" and for the involvement of participants in all the various phases present in processes of NBS.

The literature focused on how citizens' and stakeholders' motivations to participate are limited and almost equally distributed across environmental, communal, and personal drivers (see Table 8).

Several methods and tools for citizen and stakeholder participation were identified; these represent various levels of involvement and influence on the NBS process. The most used tools, in the selected publications, were questionnaires or surveys, a consultation-based method, useful to measure the needs and views of citizens. Tools, such as workshops and focus groups, were found to be less used; 
however, they were useful in bringing together decision-makers and interest groups and initiating mutual exchange of views, experiences, expertise, etc. [124]. These tools are usually used in Learning Alliances (LA) and Lab Living (LL) platforms for a more in-depth participation [135]. This type of participation enables an iterative process of knowledge exchange through a decision-making process. Additionally, LA and LL facilitate the process of collaborative learning across different scales, enabling partnerships and bottom-up innovation [135,142].

The bottom-up and citizen-led approach was the most often identified form of involving citizens and stakeholders in the NBS process, despite the fact that several articles also dealt with top-down approaches and centralized decision processes and public-private partnerships. Buijs et al. [19] proposed the concept of "mosaic governance" that goes beyond the dichotomy between top-down or bottom-up approaches, defining it as an approach that considers the specificity of the context and a balance between the expert knowledge and the autonomy of social initiatives.

\section{Conclusions}

Nature-based solutions have been studied around the world, and some existing reviews have paid attention to these urban green solutions in a general way, relating environmental and social benefits, opportunities, challenges, and barriers [9,10,15-17]. Important review research has focused on participation contributions, considering specific urban green spaces thus a comprehensive looking at the various concepts that encompass NBS approaches is still lacking $[15,20]$. Facing the ambiguity around terms and concepts (urban forest, biodiversity, urban green space, green infrastructure, biophilic infrastructure, and nature-based solutions) usually used to describe urban green projects, we present here an exercise of comprehensively include all of them. Existing review research has focused on specific terms, underlooking important developments in the area. Trying to assemble all the important publications and associated nomenclatures, our research aimed to find, organize, and highlight the most important findings from participatory experiences involving stakeholders, citizens, residents, community, and public entities. Further, this investigation pays special attention to stakeholders' and citizens' perceptions, preferences and perspectives as an a priori condition for public participation. In this manner, this research also aims to increase the awareness of managers and planners about the importance of such input to improve the quality, accuracy, and efficacy of planning and management.

Stakeholder and citizen participation or collaboration on urban green projects is increasingly recognized as promising means. The present review aimed to provide a synopsis of current research knowledge and gaps and, as well, an overview on research progress and emerging trends. From the analysis of the gathered publications, several gaps were identified that call for future investigations:

1. The lack of research applied to countries of southern Europe (which are in the forefront of climate changes) as well as the almost nonexistent research applied to Africa and South America, which preclude the establishment of a comprehensive theoretical and empirical knowledge of the participation processes during their several steps from the conceptualization to the implementation and management of NBS.

2. Despite the bulk of the literature dealing with perceptions, preferences, and perspectives of citizens and stakeholders engaged in participation processes of NBS and their anticipated benefits, only a few studies pay attention to economic benefits and those raising the quality of life in cities.

3. Few studies looked at the risks perceived by citizens and stakeholders due their involvement in NBS, and in particular, how NBS are perceived as contributing to reduce social injustice.

4. Remaining to be explored is the possibility of using the participatory process in NBS to prevent conflicts between the various interests involved.

5. New studies are needed aiming to interconnect the theoretical conceptions and the practice of participation processes in NBS, in order to adjust the citizens' and stakeholders' expected difficulties and the ones faced in reality-mitigating, in accordance, eventual frustrations of those 
involved and promoting the maintenance of collaboration during the life cycle of the implemented NBS as well as in future projects.

6. Future research should evaluate the contribution of participatory processes for the quality of decisions, the building of public trust in the decision-making process, and for the success of implemented social-learning strategies.

Author Contributions: Conceptualization: V.F., L.L., A.P.B., D.A., and T.P.; methodology: V.F., L.L., A.P.B., D.A., and T.P.; formal analysis: V.F.; investigation: V.F.; writing-original draft preparation: V.F. and A.P.B.; writing-review and editing: T.P.; supervision: T.P, and L.L. All authors have read and agreed to the published version of the manuscript.

Funding: This research was funded by the Foundation for Science and Technology (FCT), grant number PTDC/GES-URB/31928/2017.

Acknowledgments: This paper was financed by the FCT- Fundação para a Ciência e Tecnologia through project "Improving life in a changing urban environment through Biophilic Design".

Conflicts of Interest: The authors declare no conflict of interest.

\section{References}

1. European Commission. Towards an EU Research and Innovation Policy Agenda for Nature-Based Solutions \& Re-Naturing Cities: Final Report of the Horizon 2020 Expert Group on Nature-Based Solutions and Re-Naturing Cities; European Commission: Brussels, Belgium, 2015.

2. Lafortezza, R.; Sanesi, G. Nature-based solutions: Settling the issue of sustainable urbanization. Environ. Res. 2018, 172, 394-398. [CrossRef] [PubMed]

3. Xue, F.; Gou, Z.; Lau, S.S.Y.; Lau, S.K.; Chung, K.H.; Zhang, J. From biophilic design to biophilic urbanism: Stakeholders' perspectives. J. Clean. Prod. 2019, 211, 1444-1452. [CrossRef]

4. Pauleit, S.; Zölch, T.; Hansen, R.; Randrup, T.B.; van den Bosch, C.K. Nature-Based Solutions and Climate Change-Four Shades of Green; Springer International Publishing: Cham, Switzerland, 2017; pp. 29-49.

5. Lafortezza, R.; Chen, J.; van den Bosch, C.K.; Randrup, T.B. Nature-based solutions for resilient landscapes and cities. Environ. Res. 2018, 165, 431-441. [CrossRef] [PubMed]

6. Escobedo, F.J; Giannico, V.; Jim, C.Y.; Sanesi, G.; Lafortezza, R. Urban forests, ecosystem services, green infrastructure and nature-based solutions: Nexus or evolving metaphors? Urban For. Urban Green. 2019, 37, 3-12. [CrossRef]

7. Eggermont, H.; Balian, E.; Azevedo, M.N.; Beumer, V.; Brodin, T.; Claudet, J.; Fady, B.; Grube, M.; Keune, H.; Lamarque, P.; et al. Nature-based solutions: New influence for environmental management and research in Europe. GAIA 2015, 24, 243-248. [CrossRef]

8. Raymond, C.M.; Frantzeskaki, N.; Kabisch, N.; Berry, P.; Breil, M.; Nita, M.R.; Geneletti, D.; Calfapietra, C. A framework for assessing and implementing the co-benefits of nature-based solutions in urban areas. Environ. Sci. Policy 2017, 77, 15-24. [CrossRef]

9. Parker, J.; de Baro, M.E.Z. Green infrastructure in the urban environment: A systematic quantitative review. Sustainability 2019, 11, 3182. [CrossRef]

10. Sarabi, S.E.; Han, Q.; Romme, A.G.; de Vries, B.; Wendling, L. Key Enablers of and Barriers to the Uptake and Implementation of Nature-Based Solutions in Urban Settings: A Review. Resources 2019, 8, 121. [CrossRef]

11. Coles, R.W.; Bussey, S.C. Urban forest landscapes in the UK-progressing the social agenda. Landsc. Urban Plan. 2000, 52, 181-188. [CrossRef]

12. Sipilä, M.; Tyrväinen, L. Evaluation of collaborative urban forest planning in Helsinki, Finland. Urban For. Urban Green. 2005, 4, 1-12. [CrossRef]

13. Mabelis, A.A.; Maksymiuk, G. Public participation in green urban policy: Two strategies compared. Int. J. Biodivers. Sci. Manag. 2009, 5, 63-75. [CrossRef]

14. Kabisch, N.; Frantzeskaki, N.; Pauleit, S.; Naumann, S.; Davis, M.; Artmann, M.; Haase, D.; Knapp, S.; Korn, H.; Stadler, J.; et al. Nature-based solutions to climate change mitigation and adaptation in urban areas: Perspectives on indicators, knowledge gaps, barriers, and opportunities for action. Ecol. Soc. 2016, 21, 39. [CrossRef] 
15. Parker, J.; Simpson, G.D. Public green infrastructure contributes to city livability: A systematic quantitative review. Land 2018, 7, 161. [CrossRef]

16. Venkataramanan, V.; Packman, A.I.; Peters, D.R.; Lopez, D.; McCuskey, D.J.; McDonald, R.I.; Miller, W.M.; Young, S.L. A systematic review of the human health and social well-being outcomes of green infrastructure for stormwater and flood management. J. Environ. Manag. 2019, 246, 868-880. [CrossRef] [PubMed]

17. Zuniga-Teran, A.A.; Gerlak, A.K. A multidisciplinary approach to analyzing questions of justice issues in urban greenspace. Sustainability 2019, 11, 3055. [CrossRef]

18. Albert, C.; Schröter, B.; Haase, D.; Brillinger, M.; Henze, J.; Herrmann, S.; Gottwald, S.; Guerrero, P.; Nicolas, C.; Matzdorf, B. Addressing societal challenges through nature-based solutions: How can landscape planning and governance research contribute? Landsc. Urban Plan. 2019, 182, 12-21. [CrossRef]

19. Buijs, A.E.; Mattijssen, T.J.; Van der Jagt, A.P.; Ambrose-Oji, B.; Andersson, E.; Elands, B.H.; Steen Møller, M. Active citizenship for urban green infrastructure: Fostering the diversity and dynamics of citizen contributions through mosaic governance. Curr. Opin. Environ. Sustain. 2016, 22, 1-6. [CrossRef]

20. Fors, H.; Molin, J.F.; Murphy, M.A.; van den Bosch, C.K. User participation in urban green spaces-For the people or the parks? Urban For. Urban Green. 2015, 14, 722-734. [CrossRef]

21. Popoola, L.; Ajewole, O. Public perceptions of urban forests in Ibadan, Nigeria: Implications for environmental conservation. Arboric. J. 2001, 25, 1-22. [CrossRef]

22. Sanesi, G.; Chiarello, F. Residents and urban green spaces: The case of Bari. Urban For. Urban Green. 2006, 4, 125-134. [CrossRef]

23. Jim, C.Y.; Chen, W.Y. Perception and attitude of residents toward urban green spaces in Guangzhou (China). Environ. Manag. 2006, 38, 338-349. [CrossRef] [PubMed]

24. Forzieri, G.; Alessandra, B.; e Silva, F.B.; Herrera, M.A.M.; Leblois, A.; Lavalle, C.; Jeroen, C.J.H.; Feyen, L. Escalating impacts of climate extremes on critical infrastructures in Europe. Glob. Environ. Chang. 2018, 48, 97-107. [CrossRef] [PubMed]

25. Chelleri, L.; Kua, H.W.; Sánchez, J.P.R.; Md Nahiduzzaman, K.; Thondhlana, G. Are people responsive to a more sustainable, decentralized, and user-driven management of urban metabolism? Sustainability 2016, 8 , 275. [CrossRef]

26. Barnhill, K.; Smardon, R. Gaining ground: Green infrastructure attitudes and perceptions from stakeholders in Syracuse, New York. Environ. Pract. 2012, 14, 6-16. [CrossRef]

27. Keith, S.J.; Larson, L.R.; Shafer, C.S.; Hallo, J.C.; Fernandez, M. Greenway use and preferences in diverse urban communities: Implications for trail design and management. Landsc. Urban Plan. 2018, 172, 47-59. [CrossRef]

28. Campbell-Arvai, V. Engaging urban nature: Improving our understanding of public perceptions of the role of biodiversity in cities. Urban Ecosyst. 2019, 22, 409-423. [CrossRef]

29. Buchel, S.; Frantzeskaki, N. Citizens' voice: A case study about perceived ecosystem services by urban park users in Rotterdam, the Netherlands. Ecosyst. Serv. 2015, 12, 169-177. [CrossRef]

30. Miller, S.M.; Montalto, F.A. Stakeholder perceptions of the ecosystem services provided by Green Infrastructure in New York City. Ecosyst. Serv. 2019, 37, 100928. [CrossRef]

31. Rink, D.; Arndt, T. Investigating perception of green structure configuration for afforestation in urban brownfield development by visual methods-A case study in Leipzig, Germany. Urban For. Urban Green. 2016, 15, 65-74. [CrossRef]

32. Huang, S.C.L. Park user preferences for establishing a sustainable forest park in Taipei, Taiwan. Urban For. Urban Green. 2014, 13, 839-845. [CrossRef]

33. Barau, A.S. Perceptions and contributions of households towards sustainable urban green infrastructure in Malaysia. Habitat Int. 2015, 47, 285-297. [CrossRef]

34. Conedera, M.; Del Biaggio, A.; Seeland, K.; Moretti, M.; Home, R. Residents' preferences and use of urban and peri-urban green spaces in a Swiss mountainous region of the Southern Alps. Urban For. Urban Green. 2015, 14, 139-147. [CrossRef]

35. Qiu, L.; Nielsen, A.B. Are perceived sensory dimensions a reliable tool for urban green space assessment and planning? Landsc. Res. 2015, 40, 834-854. [CrossRef]

36. Rupprecht, C.D.D.; Byrne, J.A.; Ueda, H.; Lo, A.Y. “It's real, not fake like a park”: Residents' perception and use of informal urban green-space in Brisbane, Australia and Sapporo, Japan. Landsc. Urban Plan. 2015, 143, 205-218. [CrossRef] 
37. Larson, L.R.; Keith, S.J.; Fernandez, M.; Hallo, J.C.; Shafer, C.S.; Jennings, V. Ecosystem services and urban greenways: What's the public's perspective? Ecosyst. Serv. 2016, 22, 111-116. [CrossRef]

38. Ives, C.D.; Oke, C.; Hehir, A.; Gordon, A.; Wang, Y.; Bekessy, S.A. Capturing residents' values for urban green space: Mapping, analysis and guidance for practice. Landsc. Urban Plan. 2017, 161, 32-43. [CrossRef]

39. Korpilo, S.; Virtanen, T.; Saukkonen, T.; Lehvävirta, S. More than A to B: Understanding and managing visitor spatial behaviour in urban forests using public participation GIS. J. Environ. Manag. 2018, 207, 124-133. [CrossRef]

40. Panagopoulos, T.; Tampakis, S.; Karanikola, P.; Karipidou-Kanari, A.; Kantartzis, A. The usage and perception of pedestrian and cycling streets on residents' well-being in Kalamaria, Greece. Land 2018, 7, 100. [CrossRef]

41. Guenat, S.; Dougill, A.J.; Kunin, W.E.; Dallimer, M. Untangling the motivations of different stakeholders for urban greenspace conservation in sub-Saharan Africa. Ecosyst. Serv. 2019, 36, 100904. [CrossRef]

42. Gwedla, N.; Shackleton, C.M. Perceptions and preferences for urban trees across multiple socio-economic contexts in the Eastern Cape, South Africa. Landsc. Urban Plan. 2019, 189, 225-234. [CrossRef]

43. Peckham, S.C.; Duinker, P.N.; Ordóñez, C. Urban forest values in Canada: Views of citizens in Calgary and Halifax. Urban For. Urban Green. 2013, 12, 154-162. [CrossRef]

44. Yen, Y.; Wang, Z.; Shi, Y.; Soeung, B. An assessment of the knowledge and demand of young residents regarding the ecological services of urban green spaces in Phnom Penh, Cambodia. Sustainability 2016, 8, 523. [CrossRef]

45. Faivre, N.; Fritz, M.; Freitas, T.; de Boissezon, B.; Vandewoestijne, S. Nature-Based Solutions in the EU: Innovating with nature to address social, economic and environmental challenges. Environ. Res. 2017, 159, 509-518. [CrossRef] [PubMed]

46. Duan, J.; Wang, Y.; Fan, C.; Xia, B.; de Groot, R. Perception of urban environmental risks and the effects of urban green infrastructures (UGIs) on human well-being in four public green spaces of Guangzhou, China. Environ. Manag. 2018, 62, 500-517. [CrossRef] [PubMed]

47. Nath, T.K.; Zhe Han, S.S.; Lechner, A.M. Urban green space and well-being in Kuala Lumpur, Malaysia. Urban For. Urban Green. 2018, 36, 34-41. [CrossRef]

48. Zwierzchowska, I.; Hof, A.; Iojă, I.C.; Mueller, C.; Poniży, L.; Breuste, J.; Mizgajski, A. Multi-scale assessment of cultural ecosystem services of parks in Central European cities. Urban For. Urban Green. 2018, 30, 84-97. [CrossRef]

49. Gashu, K.; Gebre-Egziabher, T.; Wubneh, M. Local communities' perceptions and use of urban green infrastructure in two Ethiopian cities: Bahir Dar and Hawassa. J. Environ. Plan. Manag. 2020, 63, 287-316. [CrossRef]

50. Giannakis, E.; Bruggeman, A.; Poulou, D.; Zoumides, C.; Eliades, M. Linear parks along urban rivers: Perceptions of thermal comfort and climate change adaptation in Cyprus. Sustainability 2016, 8, 1023. [CrossRef]

51. Meyer, M.A.; Schulz, C. Do ecosystem services provide an added value compared to existing forest planning approaches in Central Europe? Ecol. Soc. 2017, 22, 6. [CrossRef]

52. Shwartz, A.; Turbé, A.; Simon, L.; Julliard, R. Enhancing urban biodiversity and its influence on city-dwellers: An experiment. Biol. Conserv. 2014, 171, 82-90. [CrossRef]

53. Wang, Y.; Kotze, D.J.; Vierikko, K.; Niemelä, J. What makes urban greenspace unique-Relationships between citizens' perceptions on unique urban nature, biodiversity and environmental factors. Urban For. Urban Green. 2019, 42, 1-9. [CrossRef]

54. Conway, T.M.; Yip, V. Assessing residents' reactions to urban forest disservices: A case study of a major storm event. Landsc. Urban Plan. 2016, 153, 1-10. [CrossRef]

55. Paul, S.; Nagendra, H. Factors influencing perceptions and use of urban nature: Surveys of park visitors in Delhi. Land 2017, 6, 27. [CrossRef]

56. Fernandes, C.O.; da Silva, I.M.; Teixeira, C.P.; Costa, L. Between tree lovers and tree haters. Drivers of public perception regarding street trees and its implications on the urban green infrastructure planning. Urban For. Urban Green. 2019, 37, 97-108. [CrossRef]

57. Ostoić, S.K.; van den Bosch, C.C.; Vuletić, D.; Stevanov, M.; Živojinović, I.; Mutabdžija-Bećirović, S.; Lazarević, J.; Stojanova, B.; Blagojević, D.; Stojanovska, M.; et al. Citizens' perception of and satisfaction with urban forests and green space: Results from selected Southeast European cities. Urban For. Urban Green. 2017, 23, 93-103. [CrossRef] 
58. Rahnema, S.; Sedaghathoor, S.; Allahyari, M.S.; Damalas, C.A.; Bilali, H. El Preferences and emotion perceptions of ornamental plant species for green space designing among urban park users in Iran. Urban For. Urban Green. 2019, 39, 98-108. [CrossRef]

59. Tsantopoulos, G.; Varras, G.; Chiotelli, E.; Fotia, K.; Batou, M. Public perceptions and attitudes toward green infrastructure on buildings: The case of the metropolitan area of Athens, Greece. Urban For. Urban Green. 2018, 34, 181-195. [CrossRef]

60. Koo, J.C.; Park, M.S.; Youn, Y.C. Preferences of urban dwellers on urban forest recreational services in South Korea. Urban For. Urban Green. 2013, 12, 200-210. [CrossRef]

61. Zhang, H.; Chen, B.; Sun, Z.; Bao, Z. Landscape perception and recreation needs in urban green space in Fuyang, Hangzhou, China. Urban For. Urban Green. 2013, 12, 44-52. [CrossRef]

62. Baur, J.W.R.; Tynon, J.F.; Ries, P.; Rosenberger, R.S. Public attitudes about urban forest ecosystem services management: A case study in Oregon cities. Urban For. Urban Green. 2016, 17, 42-53. [CrossRef]

63. Arnberger, A.; Allex, B.; Eder, R.; Ebenberger, M.; Wanka, A.; Kolland, F.; Wallner, P.; Hutter, H.P. Elderly resident's uses of and preferences for urban green spaces during heat periods. Urban For. Urban Green. 2017, 21, 102-115. [CrossRef]

64. Derkzen, M.L.; van Teeffelen, A.J.A.; Verburg, P.H. Green infrastructure for urban climate adaptation: How do residents' views on climate impacts and green infrastructure shape adaptation preferences? Landsc. Urban Plan. 2017, 157, 106-130. [CrossRef]

65. Pietrzyk-Kaszyńska, A.; Czepkiewicz, M.; Kronenberg, J. Eliciting non-monetary values of formal and informal urban green spaces using public participation GIS. Landsc. Urban Plan. 2017, 160, 85-95. [CrossRef]

66. Ayala-Azcárraga, C.; Diaz, D.; Zambrano, L. Characteristics of urban parks and their relation to user well-being. Landsc. Urban Plan. 2019, 189, 27-35. [CrossRef]

67. Hwang, Y.H.; Yue, Z.E.J.; Ling, S.K.; Tan, H.H.V. It's ok to be wilder: Preference for natural growth in urban green spaces in a tropical city. Urban For. Urban Green. 2019, 38, 165-176. [CrossRef]

68. Ramer, H.; Nelson, K.C.; Spivak, M.; Watkins, E.; Wolfin, J.; Pulscher, M.L. Exploring park visitor perceptions of 'flowering bee lawns' in neighborhood parks in Minneapolis, MN, US. Landsc. Urban Plan. 2019, 189, 117-128. [CrossRef]

69. Caula, S.; Hvenegaard, G.T.; Marty, P. The influence of bird information, attitudes, and demographics on public preferences toward urban green spaces: The case of Montpellier, France. Urban For. Urban Green. 2009, 8, 117-128. [CrossRef]

70. Karanikola, P.; Panagopoulos, T.; Tampakis, S. Weekend visitors' views and perceptions at an urban national forest park of Cyprus during summertime. J. Outdoor Recreat. Tour. 2017, 17, 112-121. [CrossRef]

71. Menconi, M.E.; Grohmann, D. Participatory retrofitting of school playgrounds: Collaboration between children and university students to develop a vision. Think. Sk. Creat. 2018, 29, 71-86. [CrossRef]

72. Shams, I.; Barker, A. Barriers and opportunities of combining social and ecological functions of urban greenspaces-Users' and landscape professionals' perspectives. Urban For. Urban Green. 2019, 39, 67-78. [CrossRef]

73. Lamichhane, D.; Thapa, H.B. Participatory urban forestry in Nepal: Gaps and ways forward. Urban For. Urban Green. 2012, 11, 105-111. [CrossRef]

74. Keeley, M.; Koburger, A.; Dolowitz, D.P.; Medearis, D.; Nickel, D.; Shuster, W. Perspectives on the use of green infrastructure for stormwater management in cleveland and milwaukee. Environ. Manag. 2013, 51, 1093-1108. [CrossRef] [PubMed]

75. Hoyle, H.; Jorgensen, A.; Warren, P.; Dunnett, N.; Evans, K. "Not in their front yard” The opportunities and challenges of introducing perennial urban meadows: A local authority stakeholder perspective. Urban For. Urban Green. 2017, 25, 139-149. [CrossRef]

76. Furlong, C.; Phelan, K.; Dodson, J. The role of water utilities in urban greening: A case study of Melbourne, Australia. Util. Policy 2018, 53, 25-31. [CrossRef]

77. Khoshkar, S.; Balfors, B.; Wärnbäck, A. Planning for green qualities in the densification of suburban Stockholm-Opportunities and challenges. J. Environ. Plan. Manag. 2018, 61, 2613-2635. [CrossRef]

78. Onori, A.; Lavau, S.; Fletcher, T. Implementation as more than installation: A case study of the challenges in implementing green infrastructure projects in two Australian primary schools. Urban Water J. 2018, 15, 911-917. [CrossRef] 
79. Girma, Y.; Terefe, H.; Pauleit, S. Urban green spaces use and management in rapidly urbanizing countries: The case of emerging towns of Oromia special zone surrounding Finfinne, Ethiopia. Urban For. Urban Green. 2019, 43, 126357. [CrossRef]

80. Molla, M.B.; Mekonnen, A.B. Understanding the local values of trees and forests: A strategy to improve the urban environment in Hawassa City, Southern Ethiopia. Arboric. J. 2019, 41, 1-13. [CrossRef]

81. Živojinović, I.; Wolfslehner, B. Perceptions of urban forestry stakeholders about climate change adaptation-A Q-method application in Serbia. Urban For. Urban Green. 2015, 14, 1079-1087. [CrossRef]

82. Lähde, E.; Di Marino, M. Multidisciplinary collaboration and understanding of green infrastructure Results from the cities of Tampere, Vantaa and Jyväskylä (Finland). Urban For. Urban Green. 2019, 40, 63-72. [CrossRef]

83. Rall, E.L.; Kabisch, N.; Hansen, R. A comparative exploration of uptake and potential application of ecosystem services in urban planning. Ecosyst. Serv. 2015, 16, 230-242. [CrossRef]

84. Di Marino, M.; Tiitu, M.; Lapintie, K.; Viinikka, A.; Kopperoinen, L. Integrating green infrastructure and ecosystem services in land use planning. Results from two Finnish case studies. Land Use Policy 2019, 82, 643-656. [CrossRef]

85. Bissonnette, J.F.; Dupras, J.; Messier, C.; Lechowicz, M.; Dagenais, D.; Paquette, A.; Jaeger, J.A.G.; Gonzalez, A. Moving forward in implementing green infrastructures: Stakeholder perceptions of opportunities and obstacles in a major North American metropolitan area. Cities 2018, 81, 61-70. [CrossRef]

86. Young, R.F. Planting the living city: Best practices in planning green infrastructure-Results from major U.S. cities. J. Am. Plan. Assoc. 2011, 77, 368-381. [CrossRef]

87. Chou, R.J.; Wu, C.T.; Huang, F.T. Fostering multi-functional urban agriculture: Experiences from the champions in a revitalized farm pond community in Taoyuan, Taiwan. Sustainability 2017, 9, 2097. [CrossRef]

88. Fors, H.; Jansson, M.; Nielsen, A.B. The impact of resident participation on urban woodland quality-a case study of Sletten, Denmark. Forests 2018, 9, 670. [CrossRef]

89. Harper, R.W.; Huff, E.S.; Bloniarz, D.V.; DeStefano, S.; Nicolson, C.R. Exploring the characteristics of successful volunteer-led urban forest tree committees in Massachusetts. Urban For. Urban Green. 2018, 34, 311-317. [CrossRef]

90. Kozová, M.; Dobšinská, Z.; Pauditšová, E.; Tomčíková, I.; Rakytová, I. Network and participatory governance in urban forestry: An assessment of examples from selected Slovakian cities. For. Policy Econ. 2018, 89, 31-41. [CrossRef]

91. Ugolini, F.; Sanesi, G.; Steidle, A.; Pearlmutter, D. Speaking “Green": A worldwide survey on collaboration among stakeholders in urban park design and management. Forests 2018, 9, 458. [CrossRef]

92. Rolf, W.; Pauleit, S.; Wiggering, H. A stakeholder approach, door opener for farmland and multifunctionality in urban green infrastructure. Urban For. Urban Green. 2019, 40, 73-83. [CrossRef]

93. Dennis, M.; James, P. Considerations in the valuation of urban green space: Accounting for user participation. Ecosyst. Serv. 2016, 21, 120-129. [CrossRef]

94. Dennis, M.; James, P. User participation in urban green commons: Exploring the links between access, voluntarism, biodiversity and well being. Urban For. Urban Green. 2016, 15, 22-31. [CrossRef]

95. Fischer, L.K.; Brinkmeyer, D.; Karle, S.J.; Cremer, K.; Huttner, E.; Seebauer, M.; Nowikow, U.; Schütze, B.; Voigt, P.; Völker, S.; et al. Biodiverse edible schools: Linking healthy food, school gardens and local urban biodiversity. Urban For. Urban Green. 2019, 40, 35-43. [CrossRef]

96. Moskell, C.; Allred, S.B. Residents' beliefs about responsibility for the stewardship of park trees and street trees in New York City. Landsc. Urban Plan. 2013, 120, 85-95. [CrossRef]

97. Gulsrud, N.M.; Hertzog, K.; Shears, I. Innovative urban forestry governance in Melbourne? Investigating "green placemaking" as a nature-based solution. Environ. Res. 2018, 161, 158-167. [CrossRef]

98. Travaline, K.; Montalto, F.; Hunold, C. Deliberative Policy Analysis and Policy-making in Urban Stormwater Management. J. Environ. Policy Plan. 2015, 17, 691-708. [CrossRef]

99. Dennis, M.; Armitage, R.P.; James, P. Appraisal of social-ecological innovation as an adaptive response by stakeholders to local conditions: Mapping stakeholder involvement in horticulture orientated green space management. Urban For. Urban Green. 2016, 18, 86-94. [CrossRef]

100. Belmeziti, A.; Cherqui, F.; Kaufmann, B. Improving the multi-functionality of urban green spaces: Relations between components of green spaces and urban services. Sustain. Cities Soc. 2018, 43, 1-10. [CrossRef] 
101. Brink, E.; Wamsler, C. Collaborative governance for climate change adaptation: Mapping citizen-municipality interactions. Environ. Policy Gov. 2018, 28, 82-97. [CrossRef]

102. Cousins, J.J. Infrastructure and institutions: Stakeholder perspectives of stormwater governance in Chicago. Cities 2017, 66, 44-52. [CrossRef]

103. Mattijssen, T.J.M.; van der Jagt, A.P.N.; Buijs, A.E.; Elands, B.H.M.; Erlwein, S.; Lafortezza, R. The long-term prospects of citizens managing urban green space: From place-making to place-keeping? Urban For. Urban Green. 2017, 26, 78-84. [CrossRef]

104. Mensah, C.A.; Andres, L.; Baidoo, P.; Eshun, J.K.; Antwi, K.B. Community Participation in Urban Planning: The Case of Managing Green Spaces in Kumasi, Ghana. Urban Forum 2017, 28, 125-141. [CrossRef]

105. Liu, L.; Jensen, M.B. Green infrastructure for sustainable urban water management: Practices of five forerunner cities. Cities 2018, 74, 126-133. [CrossRef]

106. Yamaki, K. Role of social networks in urban forest management collaboration: A case study in northern Japan. Urban For. Urban Green. 2016, 18, 212-220. [CrossRef]

107. Asah, S.T.; Blahna, D.J. Motivational functionalism and urban conservation stewardship: Implications for volunteer involvement. Conserv. Lett. 2012, 5, 470-477. [CrossRef]

108. Shan, X.Z. Attitude and willingness toward participation in decision-making of urban green spaces in China. Urban For. Urban Green. 2012, 11, 211-217. [CrossRef]

109. Zare, S.; Namiranian, M.; Feghhi, J.; Fami, H.S. Factors encouraging and restricting participation in urban forestry (Case study of Tehran, Iran). Arboric. J. 2015, 37, 224-237. [CrossRef]

110. Beery, T. Engaging the private homeowner: Linking climate change and green stormwater infrastructure. Sustainability 2018, 10, 4791. [CrossRef]

111. Fors, H.; Wiström, B.; Nielsen, A.B. Personal and environmental drivers of resident participation in urban public woodland management-A longitudinal study. Landsc. Urban Plan. 2019, 186, 79-90. [CrossRef]

112. Murphy, A.; Enqvist, J.P.; Tengö, M. Place-making to transform urban social-ecological systems: Insights from the stewardship of urban lakes in Bangalore, India. Sustain. Sci. 2019, 14, 607-623. [CrossRef]

113. Green, O.O.; Shuster, W.D.; Rhea, L.K.; Garmestani, A.S.; Thurston, H.W. Identification and induction of human, social, and cultural capitals through an experimental approach to stormwater management. Sustainability 2012, 4, 1669-1682. [CrossRef]

114. Lewis, O.; Home, R.; Kizos, T. Digging for the roots of urban gardening behaviours. Urban For. Urban Green. 2018, 34, 105-113. [CrossRef]

115. Lieberherr, E.; Green, O.O. Green infrastructure through citizen stormwater management: Policy instruments, participation and engagement. Sustainability 2018, 10, 2099. [CrossRef]

116. Lim, T.C. An empirical study of spatial-temporal growth patterns of a voluntary residential green infrastructure program. J. Environ. Plan. Manag. 2018, 61, 1363-1382. [CrossRef]

117. Petrovic, N.; Simpson, T.; Orlove, B.; Dowd-Uribe, B. Environmental and social dimensions of community gardens in East Harlem. Landsc. Urban Plan. 2019, 183, 36-49. [CrossRef]

118. Romolini, M.; Ryan, R.L.; Simso, E.R.; Strauss, E.G. Visitors' attachment to urban parks in Los Angeles, CA. Urban For. Urban Green. 2019, 41, 118-126. [CrossRef]

119. Hunter, M.R. Impact of ecological disturbance on awareness of urban nature and sense of environmental stewardship in residential neighborhoods. Landsc. Urban Plan. 2011, 101, 131-138. [CrossRef]

120. Afzalan, N.; Muller, B. The Role of social media in green infrastructure planning: A case study of neighborhood participation in park siting. J. Urban Technol. 2014, 21, 67-83. [CrossRef]

121. Guerrero, P.; Møller, M.S.; Olafsson, A.S.; Snizek, B. Revealing cultural ecosystem services through instagram images: The potential of social media volunteered geographic information for urban green infrastructure planning and governance. Urban Plan. 2016, 1, 1-17. [CrossRef]

122. Shwartz, A.; Cheval, H.; Simon, L.; Julliard, R. Virtual garden computer program for use in exploring the elements of biodiversity people want in cities. Conserv. Biol. 2013, 27, 876-886. [CrossRef]

123. Møller, M.S.; Olafsson, A.S.; Vierikko, K.; Sehested, K.; Elands, B.; Buijs, A.; van den Bosch, C.K. Participation through place-based e-tools: A valuable resource for urban green infrastructure governance? Urban For. Urban Green. 2019, 40, 245-253. [CrossRef]

124. Janse, G.; Konijnendijk, C.C. Communication between science, policy and citizens in public participation in urban forestry-Experiences from the Neighbourwoods project. Urban For. Urban Green. 2007, 6, $23-40$. [CrossRef] 
125. Hawthorne, T.L.; Elmore, V.; Strong, A.; Bennett-Martin, P.; Finnie, J.; Parkman, J.; Harris, T.; Singh, J.; Edwards, L.; Reed, J. Mapping non-native invasive species and accessibility in an urban forest: A case study of participatory mapping and citizen science in Atlanta, Georgia. Appl. Geogr. 2015, 56, 187-198. [CrossRef]

126. Raymond, C.M.; Gottwald, S.; Kuoppa, J.; Kyttä, M. Integrating multiple elements of environmental justice into urban blue space planning using public participation geographic information systems. Landsc. Urban Plan. 2016, 153, 198-208. [CrossRef]

127. Rall, E.; Hansen, R.; Pauleit, S. The added value of public participation GIS (PPGIS) for urban green infrastructure planning. Urban For. Urban Green. 2019, 40, 264-274. [CrossRef]

128. Sun, F.; Xiang, J.; Tao, Y.; Tong, C.; Che, Y. Mapping the social values for ecosystem services in urban green spaces: Integrating a visitor-employed photography method into SolVES. Urban For. Urban Green. 2019, 38, 105-113. [CrossRef]

129. Neuenschwander, N.; Wissen Hayek, U.; Grêt-Regamey, A. Integrating an urban green space typology into procedural 3D visualization for collaborative planning. Comput. Environ. Urban Syst. 2014, 48, 99-110. [CrossRef]

130. Nilsson, K.; Åkerlund, U.; Konijnendijk, C.C.; Alekseev, A.; Caspersen, O.H.; Guldager, S.; Kuznetsov, E.; Mezenko, A.; Selikhovkin, A. Implementing urban greening aid projects-The case of St. Petersburg, Russia. Urban For. Urban Green. 2007, 6, 93-101. [CrossRef]

131. Kangas, A.; Heikkilä, J.; Malmivaara-Lämsä, M.; Löfström, I. Case Puijo-Evaluation of a participatory urban forest planning process. For. Policy Econ. 2014, 45, 13-23. [CrossRef]

132. Sturiale, L.; Scuderi, A. The evaluation of green investments in urban areas: A proposal of an eco-social-green model of the city. Sustainability 2018, 10, 4541. [CrossRef]

133. Bellamy, C.C.; van der Jagt, A.P.N.; Barbour, S.; Smith, M.; Moseley, D. A spatial framework for targeting urban planning for pollinators and people with local stakeholders: A route to healthy, blossoming communities? Environ. Res. 2017, 158, 255-268. [CrossRef] [PubMed]

134. Assmuth, T.; Hellgren, D.; Kopperoinen, L.; Paloniemi, R.; Peltonen, L. Fair blue urbanism: Demands, obstacles, opportunities and knowledge needs for just recreation beside Helsinki Metropolitan Area waters. Int. J. Urban Sustain. Dev. 2017, 9, 253-273. [CrossRef]

135. Van der Jagt, A.P.N.; Smith, M.; Ambrose-Oji, B.; Konijnendijk, C.C.; Giannico, V.; Haase, D.; Lafortezza, R.; Nastran, M.; Pintar, M.; Železnikar, Š.; et al. Co-creating urban green infrastructure connecting people and nature: A guiding framework and approach. J. Environ. Manag. 2019, 233, 757-767. [CrossRef] [PubMed]

136. Lindemann-Matthies, P.; Brieger, H. Does urban gardening increase aesthetic quality of urban areas? A case study from Germany. Urban For. Urban Green. 2016, 17, 33-41. [CrossRef]

137. Sun, N.; Hall, M. Coupling human preferences with biophysical processes: Modeling the effect of citizen attitudes on potential urban stormwater runoff. Urban Ecosyst. 2016, 19, 1433-1454. [CrossRef]

138. Jayasooriya, V.M.; Ng, A.W.M.; Muthukumaran, S.; Perera, B.J.C. Multi Criteria Decision Making in Selecting Stormwater Management Green Infrastructure for Industrial Areas Part 1: Stakeholder Preference Elicitation. Water Resour. Manag. 2019, 33, 627-639. [CrossRef]

139. Lafortezza, R.; Giannico, V. Combining high-resolution images and LiDAR data to model ecosystem services perception in compact urban systems. Ecol. Indic. 2019, 96, 87-98. [CrossRef]

140. Nordström, E.M.; Eriksson, L.O.; Öhman, K. Integrating multiple criteria decision analysis in participatory forest planning: Experience from a case study in northern Sweden. For. Policy Econ. 2010, 12, 562-574. [CrossRef]

141. Beumer, C.; Martens, P. Biodiversity in my (back)yard: Towards a framework for citizen engagement in exploring biodiversity and ecosystem services in residential gardens. Sustain. Sci. 2015, 10, 87-100. [CrossRef]

142. O'Donnell, E.C.; Lamond, J.E.; Thorne, C.R. Learning and Action Alliance framework to facilitate stakeholder collaboration and social learning in urban flood risk management. Environ. Sci. Policy 2018, 80, 1-8. [CrossRef]

143. Qiu, L.; Lindberg, S.; Nielsen, A.B. Is biodiversity attractive?-On-site perception of recreational and biodiversity values in urban green space. Landsc. Urban Plan. 2013, 119, 136-146. [CrossRef]

144. Rosol, M. Public Participation in post-fordist urban green space governance: The case of community gardens in Berlin. Int. J. Urban Reg. Res. 2010, 34, 548-563. [CrossRef] [PubMed] 
145. Faehnle, M.; Bäcklund, P.; Tyrväinen, L.; Niemelä, J.; Yli-Pelkonen, V. How can residents' experiences inform planning of urban green infrastructure? Case Finland. Landsc. Urban Plan. 2014, 130, 171-183. [CrossRef]

146. Skandrani, Z.; Prévot, A.C. Beyond green-planning political orientations: Contrasted public policies and their relevance to nature perceptions in two European capitals. Environ. Sci. Policy 2015, 52, 140-149. [CrossRef]

147. Gasperi, D.; Pennisi, G.; Rizzati, N.; Magrefi, F.; Bazzocchi, G.; Mezzacapo, U.; Stefani, M.C.; Sanyé-Mengual, E.; Orsini, F.; Gianquinto, G. Towards regenerated and productive vacant areas through urban horticulture: Lessons from Bologna, Italy. Sustainability 2016, 8, 1347. [CrossRef]

148. Kronenberg, J.; Pietrzyk-Kaszyńska, A.; Zbieg, A.; Żak, B. Wasting collaboration potential: A study in urban green space governance in a post-transition country. Environ. Sci. Policy 2015, 62, 69-78. [CrossRef]

149. Shifflett, S.D.; Newcomer-Johnson, T.; Yess, T.; Jacobs, S. Interdisciplinary collaboration on green infrastructure for urban watershed management: An Ohio case study. Water 2019, 11, 738. [CrossRef]

150. Cvejić, R.; Železnikar, Š.; Nastran, M.; Rehberger, V.; Pintar, M. Urban agriculture as a tool for facilitated urban greening of sites in transition: A case study. Urbani Izziv 2015, 26, S84-S97. [CrossRef]

151. Jerome, G. Defining community-scale green infrastructure. Landsc. Res. 2017, 42, 223-229. [CrossRef]

152. Van der Jagt, A.P.N.; Szaraz, L.R.; Delshammar, T.; Cvejić, R.; Santos, A.; Goodness, J.; Buijs, A. Cultivating nature-based solutions: The governance of communal urban gardens in the European Union. Environ. Res. 2017, 159, 264-275. [CrossRef]

153. Milanovič, N.P. Green infrastructure and urban revitalisation in Central Europe: Meeting environmental and spatial challenges in the inner city of Ljubljana, Slovenia. Urbani izziv 2015, 26, 50-64.

154. Simić, I.; Stupar, A.; Djokić, V. Building the green infrastructure of Belgrade: The importance of community greening. Sustainability 2017, 9, 1183. [CrossRef]

155. Buijs, A.; Hansen, R.; Van der Jagt, S.; Ambrose-Oji, B.; Elands, B.; Lorance Rall, E.; Mattijssen, T.; Pauleit, S.; Runhaar, H.; Stahl Olafsson, A.; et al. Mosaic governance for urban green infrastructure: Upscaling active citizenship from a local government perspective. Urban For. Urban Green. 2019, 40, 53-62. [CrossRef]

156. Ugolini, F.; Massetti, L.; Sanesi, G.; Pearlmutter, D. Knowledge transfer between stakeholders in the field of urban forestry and green infrastructure: Results of a European survey. Land Use Policy 2015, 49, 365-381. [CrossRef]

157. Schifman, L.A.; Herrmann, D.L.; Shuster, W.D.; Ossola, A.; Garmestani, A.; Hopton, M.E. Situating green infrastructure in context: A framework for adaptive socio-hydrology in cities. Water Resour. Res. 2017, 53, 10139-10154. [CrossRef]

158. Frantzeskaki, N. Seven lessons for planning nature-based solutions in cities. Environ. Sci. Policy 2019, 93, 101-111. [CrossRef]

(C) 2020 by the authors. Licensee MDPI, Basel, Switzerland. This article is an open access article distributed under the terms and conditions of the Creative Commons Attribution (CC BY) license (http://creativecommons.org/licenses/by/4.0/). 